\title{
Control over molecular motion using the cis-trans photoisomerization of the azo group
}

\author{
Estíbaliz Merino ${ }^{* 1}$ and María Ribagorda ${ }^{2}$
}

\section{Review}

Address:

${ }^{1}$ Instituto de Química Orgánica General, Centro Superior de Investigaciones Científicas (CSIC), C/ Juan de la Cierva, 3, 28006, Madrid, Spain and 2Departmento de Química Orgánica, Facultad de Ciencias, Universidad Autónoma de Madrid, 28049, Madrid, Spain

Email:

Estíbaliz Merino* - estibaliz.merino@iqog.csic.es;

María Ribagorda - maria.ribagorda@uam.es

${ }^{*}$ Corresponding author

Keywords:

azobenzenes; molecular switches; nanomachines; photoisomerization
Beilstein J. Org. Chem. 2012, 8, 1071-1090. doi:10.3762/bjoc.8.119

Received: 16 March 2012

Accepted: 21 June 2012

Published: 12 July 2012

This article is part of the Thematic Series "Molecular switches and cages".

Guest Editor: D. Trauner

(c) 2012 Merino and Ribagorda; licensee Beilstein-Institut. License and terms: see end of document.

\begin{abstract}
Control over molecular motion represents an important objective in modern chemistry. Aromatic azobenzenes are excellent candidates as molecular switches since they can exist in two forms, namely the cis $(Z)$ and trans $(E)$ isomers, which can interconvert both photochemically and thermally. This transformation induces a molecular movement and a significant geometric change, therefore the azobenzene unit is an excellent candidate to build dynamic molecular devices. We describe selected examples of systems containing an azobenzene moiety and their motions and geometrical changes caused by external stimuli.
\end{abstract}

\section{Review}

This review is based on an article published in 2009 in Anales de Química (Real Sociedad Española de Química) [1]. Azobenzene was described for the first time in 1834 [2] and one century later, in 1937, G. S. Hartley published a study of the influence of light on the configuration of $\mathrm{N}=\mathrm{N}$ double bonds [3]. The exposure of a solution of azobenzene in acetone to light allowed the discovery of the cis isomer. This finding was the starting point of the development of one of the best organic molecular switches described so far. The azobenzenes are organic molecules that present two aromatic rings linked by an azo group $(\mathrm{N}=\mathrm{N})$. They have properties that have led to some applications of great importance, mainly for the chemical industry. The azobenzenes are highly coloured compounds and belong to the group of so-called dyes FD\&C (food, drug and cosmetics). Nowadays, azobenzene dyes represent approximately $60 \%$ of the world production of industrial dyes [4-6].

In recent years, the photochromic properties of azobenzenes have attracted great interest due to the isomerization of the $\mathrm{N}=\mathrm{N}$ double bonds that occurs readily in the presence of a light source [7-9].

Like a $\mathrm{C}=\mathrm{C}$ double bond, the azobenzenes have two geometric isomers $(Z / E)$ around the $\mathrm{N}=\mathrm{N}$ double bond, the trans isomer 
$(E)$ is $\sim 12 \mathrm{kcal} \cdot \mathrm{mol}^{-1}$ more stable than the cis isomer $(Z)$ [10]. The energy barrier of the photoexcited state is $\sim 23 \mathrm{kcal} \cdot \mathrm{mol}^{-1}$, such that the trans isomer is predominant in the dark at room temperature [11].

The trans-azobenzene easily isomerizes to the cis isomer by irradiation of the trans isomer with a wavelength between $320-350 \mathrm{~nm}$. The reaction is reversible and the trans isomer is recovered when the cis isomer is irradiated with light of $400-450 \mathrm{~nm}$, or heated. For many azobenzenes, the two photochemical conversions occur on the scale of picoseconds, while the thermal relaxation of the cis isomer to the trans isomer is much slower (milliseconds to days). The photoinduced isomerization of the azobenzenes leads to a remarkable change in their physical properties, such as molecular geometry, dipole moment or absorption spectrum [12-16].

The isomerization process involves a decrease in the distance between the two carbon atoms in position 4 of the aromatic rings of azobenzene, from $9.0 \AA$ in the trans form to $5.5 \AA$ in the cis form (Figure 1) [17]. The trans-azobenzene is almost flat and has no dipole moment, whereas the cis isomer presents an angular geometry and a dipole moment of 3.0 D. One of the rings rotates to avoid steric repulsions due to facing of one of the $\pi$ clouds of one aromatic ring to the other [9]. The arrangement of the aromatic rings is also reflected in the proton nuclear magnetic resonance spectrum ( $\left.{ }^{1} \mathrm{H} \mathrm{NMR}\right)$. The signals of the $c$ is isomer appear at higher field than the signals corresponding to the trans isomer, due to the anisotropic effect of the $\pi$ cloud of the aromatic ring.

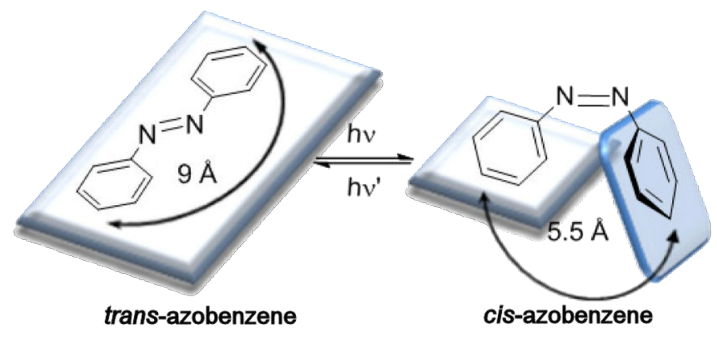

Figure 1: Photoisomerization process of azobenzene.

The UV-vis absorption spectrum of azobenzene presents two characteristic absorption bands corresponding to $\pi \rightarrow \pi^{*}$ and $\mathrm{n} \rightarrow \pi^{*}$ electronic transitions. The transition $\pi \rightarrow \pi^{*}$ is usually in the near UV region and is common to carbonate systems, such as stilbene [18]. The electronic transition $n \rightarrow \pi^{*}$ is usually located in the visible region and is due to the presence of unshared electron pairs of nitrogen atoms [19]. Due to this second electronic transition, the dynamic photoisomerization process of azobenzenes is different to the carbonate compounds [20]. Azobenzene undergoes trans-cis isomerization by $\mathrm{S}_{1} \leftarrow \mathrm{S}_{0}$ and $\mathrm{S}_{2} \leftarrow \mathrm{S}_{0}$ excitations and cis-trans isomerization by exciting into the $S_{1}$ or $S_{2}$ state [21]. The sum of the quantum yields is different to unity, which indicates multiple pathways for isomerization. In stilbene, the isomerization occurs exclusively by rotation and the quantum yield equals unity [22].

The aromatic azocompounds are classified in three types based on the order of their energetic electronic states $\pi \rightarrow \pi^{*}$ and $n \rightarrow \pi^{*}$ [11]. This order depends on the electronic nature of the aromatic rings of azobenzene. Each type of azobenzene also has a predominant colour defined by the wavelength of the maximum absorption band $\left(\lambda_{\max }\right)$ (indicated in brackets in each case):

1. Azobenzene type: The $\pi \rightarrow \pi^{*}$ band is very intense in the UV region and there is one $n \rightarrow \pi^{*}$ weaker in the visible (yellow colour). The electronic nature of the aromatic rings is very similar to simple azobenzene $(\mathrm{Ph}-\mathrm{N}=\mathrm{N}-\mathrm{Ph})$.

2. Aminoazobenzene type (o- or $\left.p-(\mathrm{X})-\mathrm{C}_{6} \mathrm{H}_{4}-\mathrm{N}=\mathrm{N}-\mathrm{Ar}\right)$ : The $\pi \rightarrow \pi^{*}$ and $n \rightarrow \pi^{*}$ bands are very close or collapsing in the UV-vis region. In this case, the azocompounds have electron-donor substituents (X) in the ortho or para positions (orange colour).

3. Pseudo-stilbene type $\left[(\mathrm{X})-\mathrm{C}_{6} \mathrm{H}_{4}-\mathrm{N}=\mathrm{N}-\mathrm{C}_{6} \mathrm{H}_{4}-(\mathrm{Y})\right]$ : The absorption band corresponding with $\pi \rightarrow \pi^{*}$ transition is shifted to red, changing the appearance order with respect to the band $n \rightarrow \pi^{*}$. The azocompounds of this type present donor substituents $(\mathrm{X})$ and electron acceptors (Y) at the 4 and 4 ' positions, respectively (push/pull system) (red colour).

The isomerization process normally involves a colour change to more intense colours. The absorption spectra of both isomers differ mainly in the following aspects (Figure 2) [23]:

Trans isomer: The absorption band $\pi \rightarrow \pi^{*}$ is very intense, with a molar extinction coefficient $(\varepsilon) \sim 2-3 \times 10^{4} \mathrm{M}^{-1} \cdot \mathrm{cm}^{-1}$. The second band $\left(\mathrm{n} \rightarrow \pi^{*}\right)$ is much weaker $\left(\varepsilon \sim 400 \mathrm{M}^{-1} \cdot \mathrm{cm}^{-1}\right)$ as this transition is not allowed in the trans isomer by the symmetry rules.

Cis isomer: The absorption band $\pi \rightarrow \pi^{*}$ is shifted to shorter wavelengths (hypsochromic effect) decreasing significantly in intensity $\left(\varepsilon \sim 7-10 \times 10^{3} \mathrm{M}^{-1} \cdot \mathrm{cm}^{-1}\right)$. The electronic transition $\mathrm{n} \rightarrow \pi^{*}(380-520 \mathrm{~nm})$ is allowed in the cis isomer, resulting in 


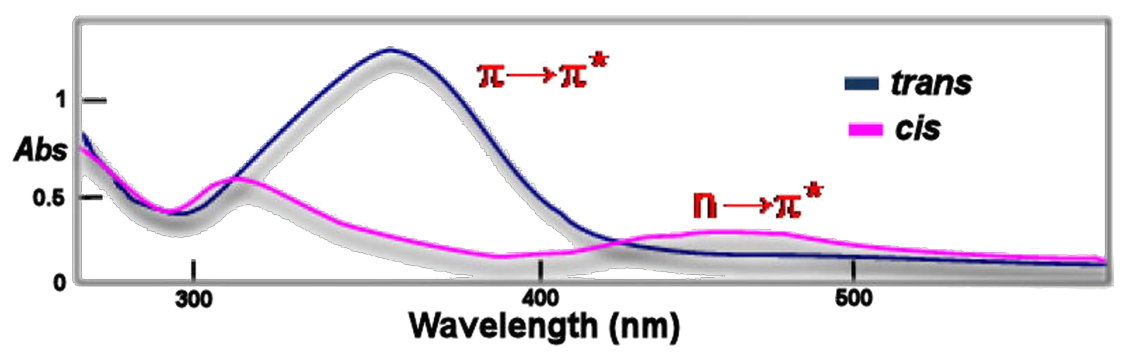

Figure 2: Representative example of an UV spectrum of an azocompound of the azobenzene type (blue line: trans isomer; magenta line: cis isomer).

an increase in the intensity $\left(\varepsilon \sim 1500 \mathrm{M}^{-1} \cdot \mathrm{cm}^{-1}\right)$ with respect to the trans isomer.

These differences allow carrying out a photochemical interconversion by irradiation with light of a certain wavelength, obtaining different proportions of the cis and trans photostationary states. The excitation caused by the wavelength is dependent on the nature of the substituents of the aryl groups. In most cases, trans $\rightarrow$ cis isomerization is promoted by irradiation with wavelengths between $320-380 \mathrm{~nm}$, while exposures to $\lambda \sim 400-450 \mathrm{~nm}$ favor the cis $\rightarrow$ trans photoreversion. The mechanism is not well established. Several mechanistic studies have been performed on the isomerization reversal route cis $\rightarrow$ trans of azobenzene to investigate the effect of the substituents on the benzene rings as well as the influence of several parameters [24-27]. The available data suggest that the isomerization of azocompounds can proceed through the reversal of one of the $\mathrm{N}-\mathrm{C}$ bonds or by the rotation of the $\mathrm{N}=\mathrm{N}$ double bond. The nonbonding electron pair of each nitrogen atom may lead to one $n \rightarrow \pi^{*}$ electronic transition $\left(\mathrm{S}_{0} \rightarrow \mathrm{S}_{1}\right)$ with inversion at the nitrogen atom (inversion mechanism) $[28,29]$. On the other hand, the isomer- ization can also occur through a rotation mechanism [11,30], which involves a $\pi \rightarrow \pi^{*}$ transition $\left(\mathrm{S}_{0} \rightarrow \mathrm{S}_{2}\right)$ (Figure 3). This mechanism is similar to that produced in the isomerization of stilbene [23].

\section{Azobenzenes as molecular switches}

A molecular switch is a molecular system that allows mechanical movements to be carried out when the system is subjected to an external stimulus, such as light, resulting in conformational and environmental changes of the switch.

The basis of a molecular switch is the reversible transformation of chemical species caused by light between two states of a molecule with different absorption spectra.

These photoisomerization processes modify the absorption spectra and can produce variations in different physicochemical properties of molecules, such as ion complexation, refractive index, electrochemical behaviour, and very significant conformational changes in polymers. There may also be variations in the organization of large assemblies of molecules in gels or liquid crystals. When polarized light is used, the photoisomeri-

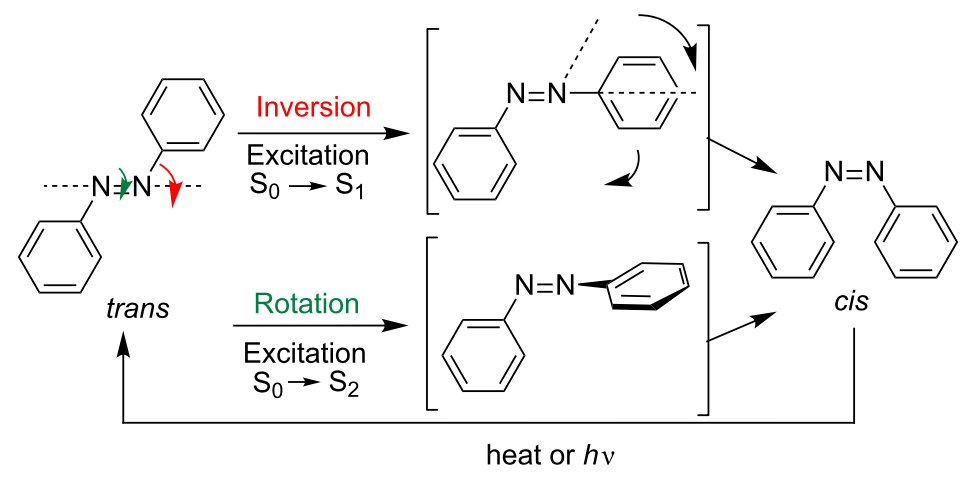

Figure 3: Mechanistic proposals for the isomerization of azobenzenes. 
zation often induces a reorganization of chromophores that can be reflected in the circular dichroism spectra.

The basic condition for a molecule to behave as a switch is the existence of two different and stable isomeric forms that interconvert when an external stimulus is applied to it

The most important requirements for a molecule to behave as a molecular switch are the following [31-35]:

1. The transformation between the two interconvertible structures that comprise the molecular switch must be produced easily and selectively by irradiation with light of a certain wavelength.

2. The thermal interconversion between two isomers should not occur in a wide temperature range, thus allowing the storage of information for an almost infinite length of time.

3. The isomers should have an appreciable resistance to fatigue (number of cycles without decomposition), with the possibility to carry out the cycle of write/erase several times, and should not cause thermal degradation or photochemical side-products.

4. The two structural forms should be easily detectable.

5. An efficient interrupt process. High quantum yields have to be achieved by using short irradiation periods.

6. The response times have to be quick to be also fast interrupting cycles.

7. It is necessary that all properties remain unchanged when the compound used as the photoswitch is a part of a macromolecular structure.

A variety of photosensitive devices, such as smart polymers [36,37], liquid crystals [38,39], intelligent enzymes [40], and various switches and molecular machines [41-48], have been developed by using the photochromic properties of azobenzene and benefiting from its easy synthesis [4,6,49-54]. The molecular motion that occurs in the photoisomerization has allowed the development of azo-structures that have grown in complexity, originality and usefulness [55-58]. This review includes some of the most outstanding examples.

\section{Photoisomerization of azobenzenes: A simple molecular motion}

The introduction of an azobenzene fragment in a molecule with biological activity [59-63], such as a protein, can allow the spatial and temporal control of a variety of biological processes through illumination, by means of the direct regulation of enzymatic activity [64-67], peptides, proteins, nucleic acids [68-76], receptors [77-82], or ion channels [83-85], or by modulation of the concentration of several labelled molecules. This strategy is very attractive because it allows control over the conformation and consequently the activity of biomolecules in a reversible way without the addition of any reagent. Structural effects caused by the isomerization can be amplified in the host or initiate a cascade of photophysical and photochemical secondary responses. The first application of an azobenzene in biology was published in the late 1960s and was used to photoregulate the activity of chymotrypsin, a digestive enzyme [86]. Later, a similar strategy was applied in functional and structural studies of the acetylcholine receptor of nicotinic type [87]. The trans $\rightarrow$ cis photoisomerization of 4,4'-trimethylammonium methyl substituted azobenzene produced an increase in the concentration of acetylcholine agonists as a result of the specific interaction of both isomers with the acetylcholine receptor that is present in excitable membranes. In this way, it is possible to control the permeability changes, allowing the ion motion during the generation of the bioelectric impulse.

The isomerization of azocompounds has been used as a synthetic tool to control the opening and closing of pores in cellular membranes, essential for the transport of ions. An illustrative example is described by Trauner, Kramer and co-workers to control the $\mathrm{K}^{+}$channels in neuronal cells (Figure 4) [88].

The azobenzene $\mathbf{1}$ is a terminal quaternary ammonium salt, thus when 1 adopts the trans configuration, the flow of $\mathrm{K}^{+}$ions is blocked. After irradiation with $\lambda=380 \mathrm{~nm}$, the cis isomer brings the aromatic rings closer, shortening its length, and hence the channel blocking is inefficient, allowing the passage of ions. The development of systems capable of photoregulating the activity of ion channels is extremely important in neurobiology. Recently, a maleimide, azobenzene and glutamate derivative (MAG) was used as a photochromic agonist of an ionotropic glutamate receptor (iGluR) (Figure 5a) [89-91]. The chromophore consists of a terminal maleimide unit, which is associated covalently to the protein via a cysteine residue, a central azobenzene unit and a glutamate head. Only the cis form of the azobenzene allows the approach of the fragment and the interaction of glutamate with the active site of the protein. When this interaction occurs, the protein folds as a clamshell, triggering the opening of the ion channel (Figure 5b).

Another recent example was described by Woolley et al. $[92,93]$. They introduced an azobenzene moiety in a polypeptide to control the $\alpha$-helical conformation and to have a synthetic tool that allows photomodulation of the very important conformation-interaction relationship in biological recognition. Peptides with pairs of cysteine residues were intramolecularly cross-linked with thiol reactive azobenzene-based photoswitches. Photoisomerization of the azobenzene changes the conformation of the peptide depending on the location of the 

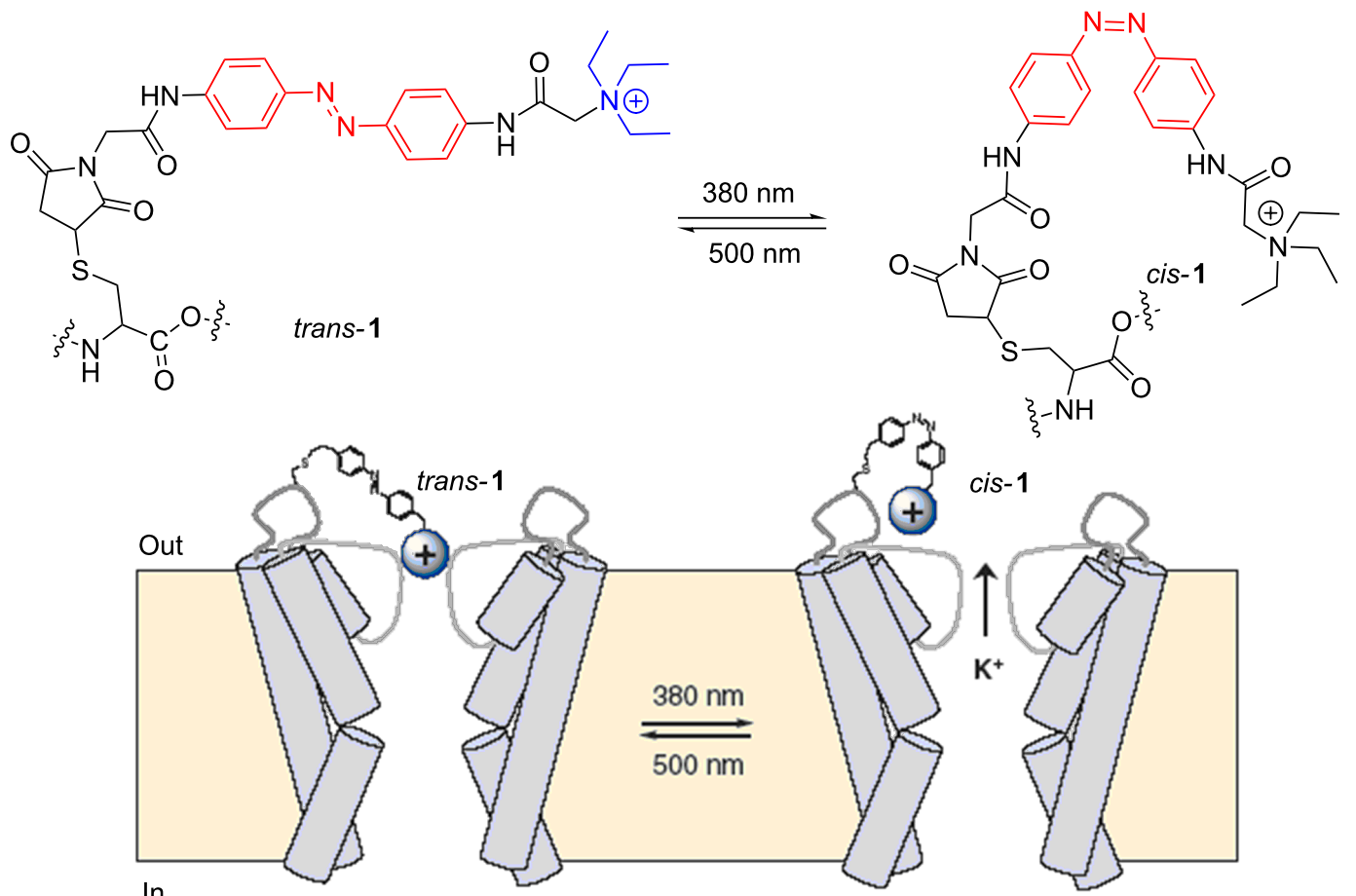

Figure 4: Representation of the photocontrol of a $\mathrm{K}^{+}$channel in the cellular membrane based on the isomerization of azocompound 1. Reprinted (adapted) with permission from Macmillan Publishers Ltd: Nat. Neurosci. 2004, 7, 1381-1386, copyright (2004).

a)
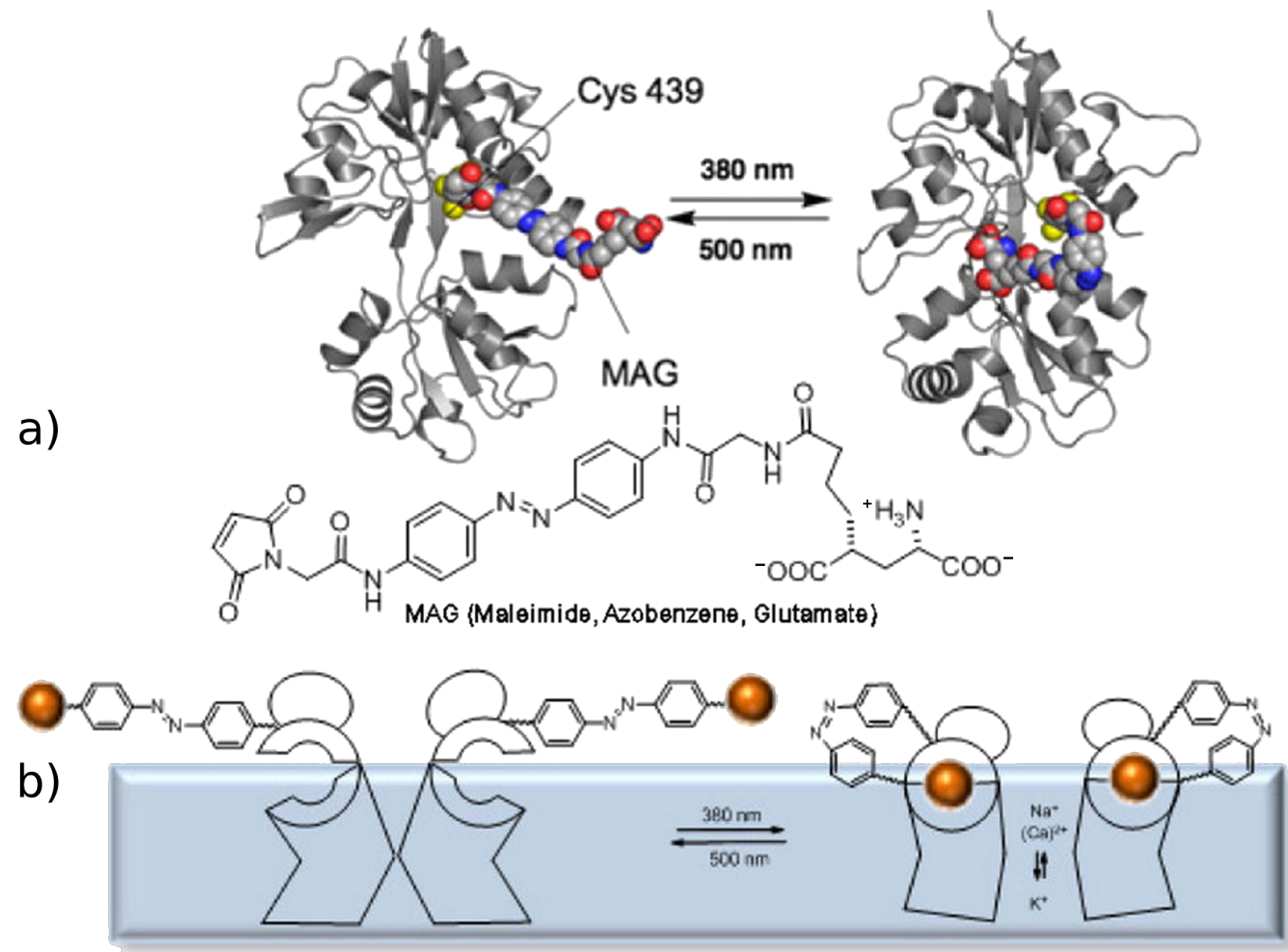

Figure 5: (a) MAG interaction with iGluR; (b) photocontrol of the opening of the ion channel by trans-cis isomerization of azobenzene. Reprinted with permission from Macmillan Publishers Ltd: Nat. Chem. Biol. 2006, 2, 47-52, copyright (2006). 
cysteine. When the azo group of polypeptide $\mathbf{2}$ is in its trans form, it retains its affinity for DNA and its $\alpha$-helical conformation. The photoisomerization leads to the cis isomer, which disrupts this helicity inhibiting the association with DNA. The photoreversion to the trans isomer recovers again the final conformation of the $\alpha$-helix of DNA. In 2011, the same group carried out the attachment of a fluorescent dye close to the photoswitch giving rise to a fluorescence change upon isomerization. The introduction of azobenzene-modified biomolecules in zebrafish proved that the photochemistry of azobenzenes was similar in vivo and in vitro, and that appropriate azobenzenes could be stable in vivo for days (Figure 6) [94].

The photochromic properties of azobenzenes also find applications in "host-guest" recognition $[95,96]$. For example, the bisazo compound 3 behaves as an excellent receptor of guanidinium ions by hydrogen-bonding interactions. The recognition is very effective when the azobenzene adopts the cis configuration (Figure 7) [95].

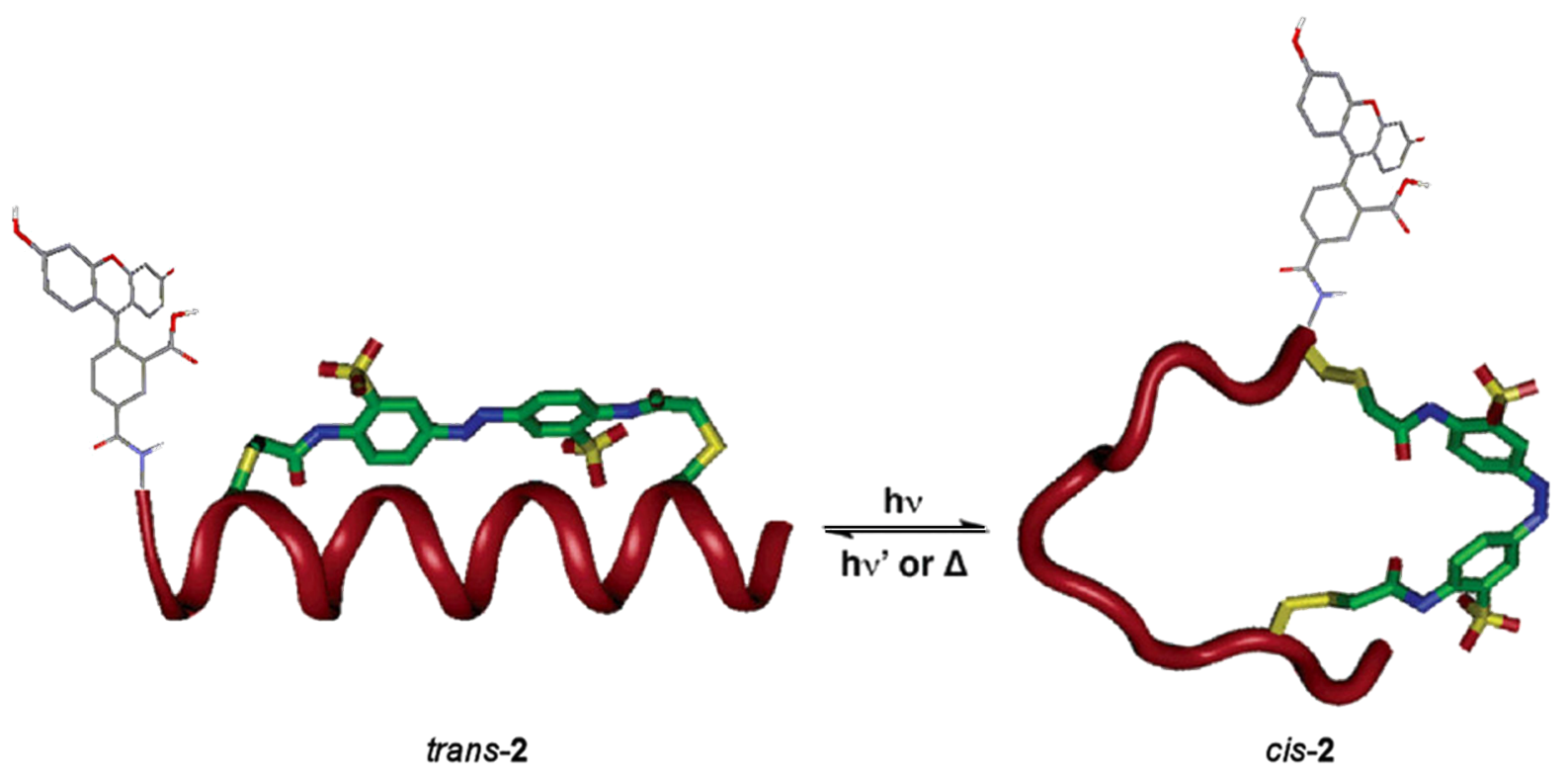

Figure 6: Photocontrol of the structure of the a-helix in the polypeptide azoderivative 2. Reprinted (adapted) with permission from J. Am. Chem. Soc. 2005, 127, 15624-15625. Copyright (2005) American Chemical Society.

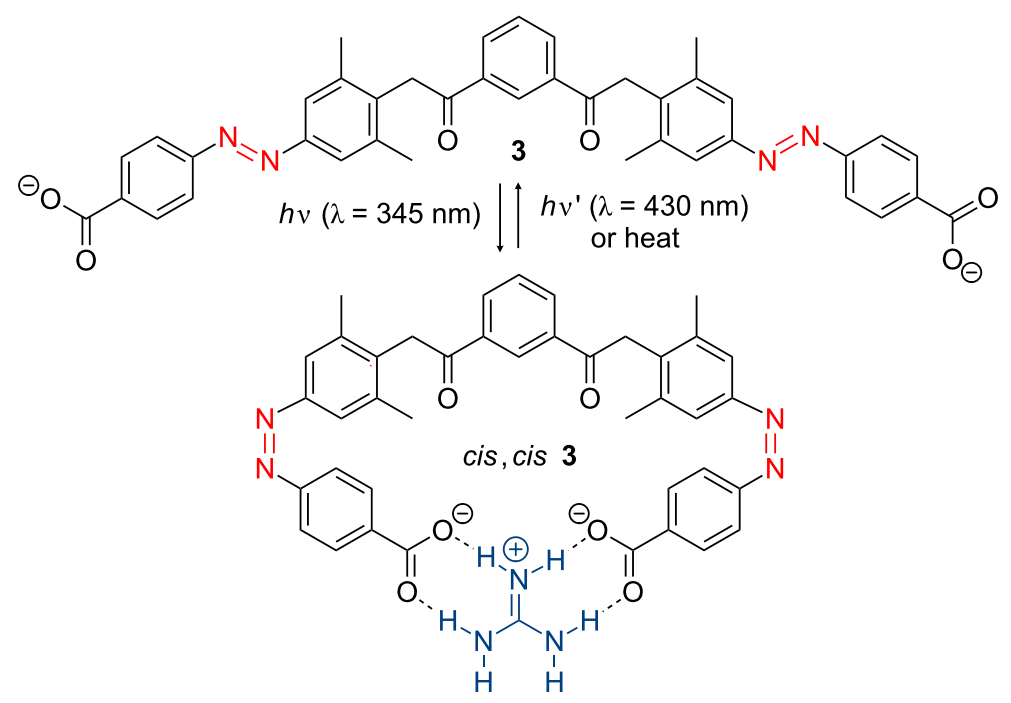

Figure 7: Recognition of a guanidinium ion by a cis, cis-bis-azo derivative 3 . 


\section{Azobenzene-based molecular devices}

Among the systems with the inclusion and complexation properties of ions [97-100], several classes of compounds called azophanes, azocrowns [101-104], azocryptands, azocyclodextrins and azocalixarenes [105-107] have been described. The introduction of an azobenzene in these systems enables the photocontrol of the bonding properties of these molecules. The inclusion and complexation properties of some ions are more selective in one isomer that in the other. For example, the system of azocrown $\mathbf{4}$ shows a high selectivity for $\mathrm{Rb}^{+}$and $\mathrm{Cs}^{+}$ ions [108]. The photoisomerization yields a similar motion to that of a butterfly, and only in the case of the cis isomer are the cations located between the two rings, yielding a "sandwich" structure (Figure 8). The ability of the azo compound 4 to remove cations from an aqueous solution increases in the order $\mathrm{Na}^{+}<\mathrm{K}^{+}<\mathrm{Rb}^{+}<\mathrm{Cs}^{+}$. According to these properties, compound 4 could be used as a selective transport system controlled by light.

The $\beta$-cyclodextrin-type structure, schematically represented in Figure 9 as 5, acknowledges the bipyridinium fragment of diarylazobenzene $\mathbf{6}$ by formation of an inclusion complex of trans $-5+6$. This inclusion complex evolves in a reversible way when it is irradiated. The process is especially interesting for

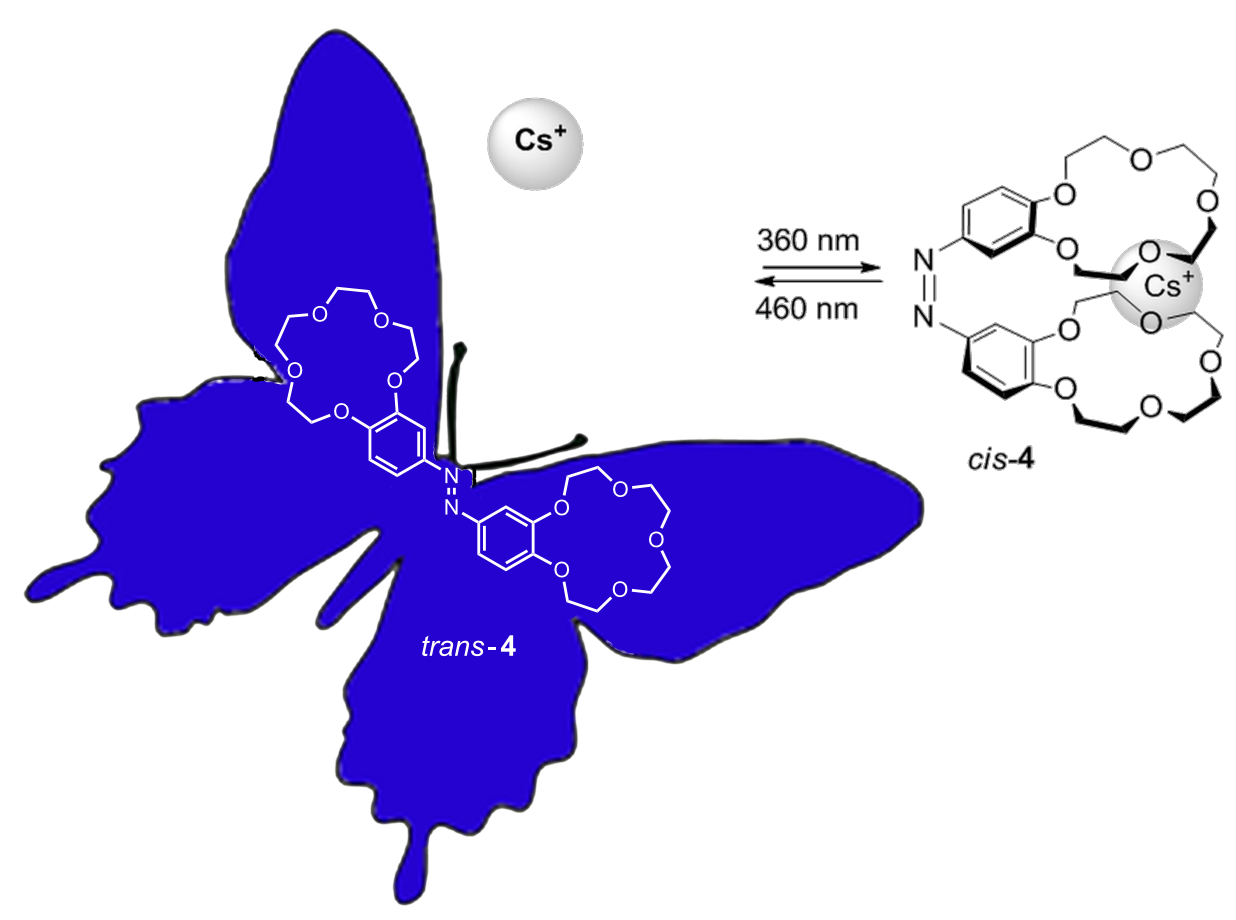

Figure 8: Recognition of cesium ions by cis-azo derivative 4 .
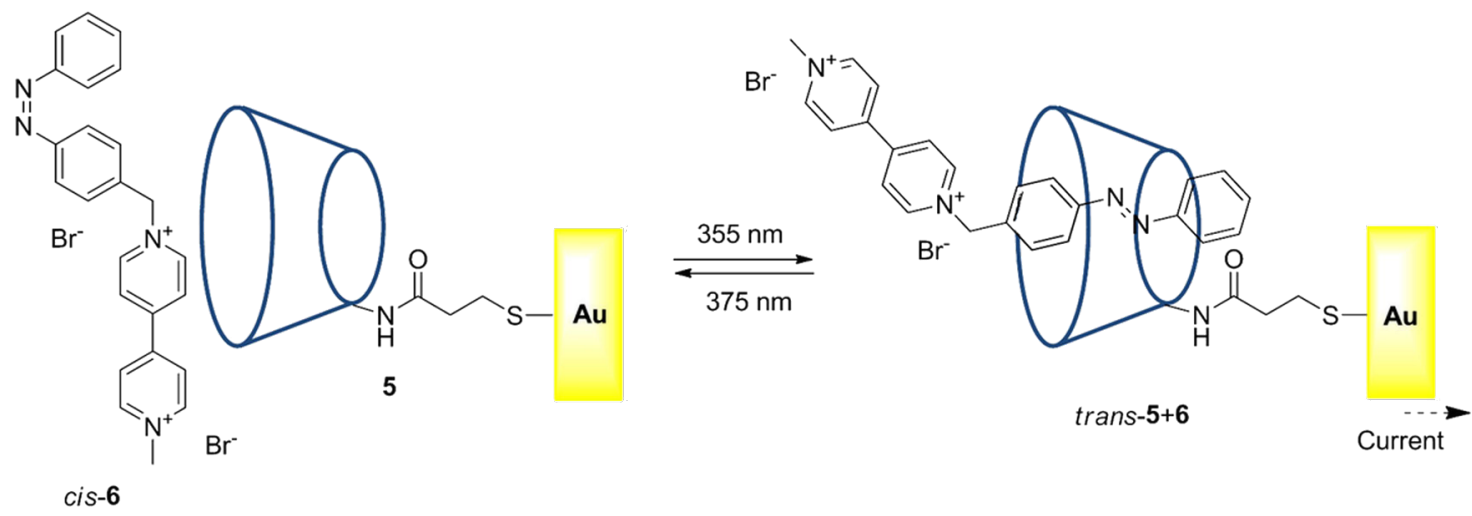

Figure 9: Photocontrolled formation of an inclusion complex of cyclodextrin trans-azo 5+6. 
the translation of the optical signals recorded by the bipyridinium azobenzene $\mathbf{6}$ via a $\beta$-cyclodextrin single phase prepared on a gold electrode [109].

In 2003, a molecular machine based on a pseudorotaxane was described [110]. Assembly between 7 and 8 occurs only when the azobenzene 7 adopts the cis configuration. The pseudorotaxane $7+8$ is disassembled into its two components when the isomerization to trans-azobenzene occurs by an external stimulus (Figure 10).

\section{Hinge molecular}

Tamaoki et al. [111] designed a molecular device capable of photo-emulating a hinge motion. This switch consists in two azobenzene units that share a fragment with two coplanar xanthenes (Figure 11). The photoisomerization of the system forces a molecular motion similar to a hinge, in which the two aromatic rings are arranged at an angle of $90^{\circ}$. The photoisomerization process involves three isomeric forms: (trans,trans), (trans,cis) and (cis,cis). The heats of formation of the three isomers were determined by ab initio quantum chemical calculations. The isomers (trans,trans) and (cis,cis) are 28 and $2.6 \mathrm{kcal} \cdot \mathrm{mol}^{-1}$ more stable than the intermediate isomer, respectively. The large energy difference between (trans,trans) and (trans,cis) isomers indicates the ring strain that exists in the (trans,cis) isomer, and the thermal isomerization from (cis,cis) to (trans,cis) is forbidden. The half-life of (trans,cis)-isomer is only $28 \mathrm{~s}$ at $23{ }^{\circ} \mathrm{C}$. In these systems, in which the photochem-<smiles>CCN(CC)C(=O)c1ccc(C(=O)Nc2cc(C(C)(C)C)cc3c2Oc2c(/N=N/c4ccccc4)cc(C(C)(C)C)cc2C3(C)C)cc1</smiles>

7

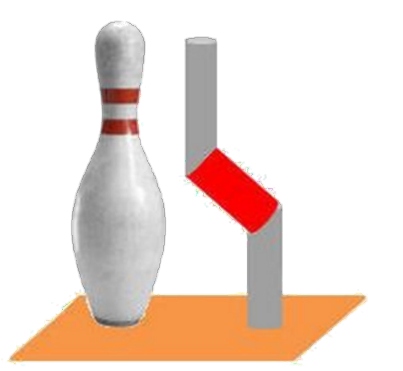

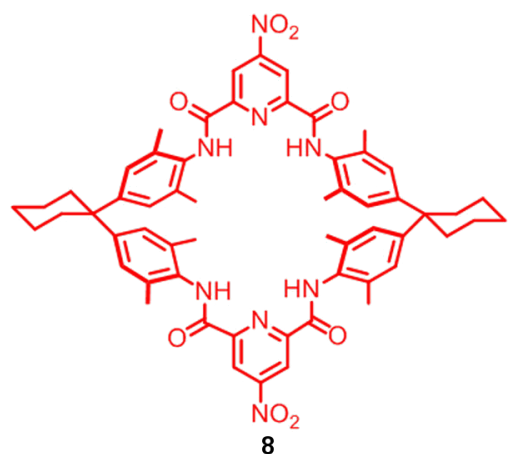

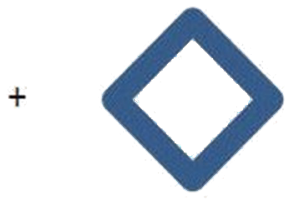

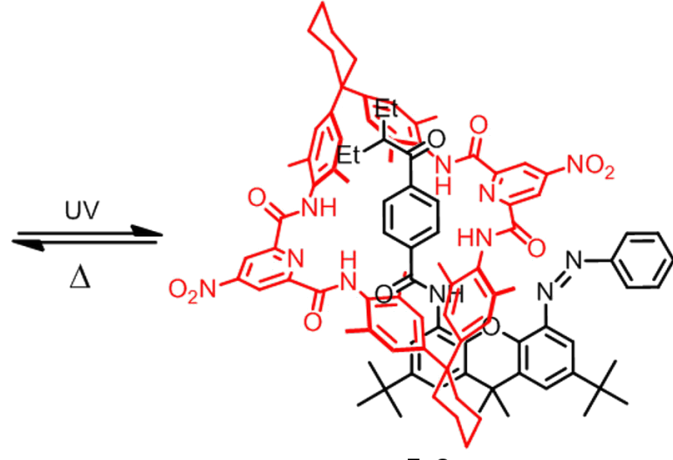

$7+8$

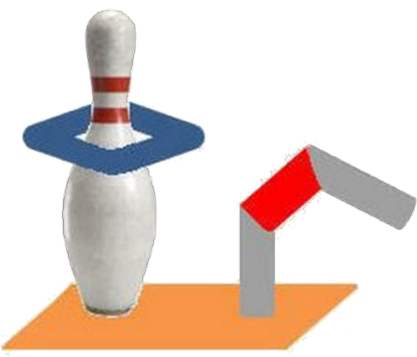

Figure 10: Pseudorotaxane-based molecular machine.

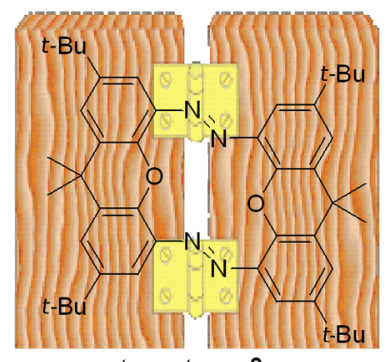

trans,trans-9

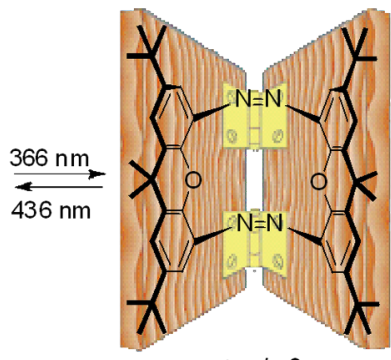

cis, cis-9 
ical reaction intermediate has a short half-life and the final (cis,cis)-product is more stable than the intermediate, the photochemical yield is highly dependent on the used light intensity [112-114].

\section{Molecular threader}

Stoddart, Balzani et al. [115,116] created an intelligent molecular device (trans-10-11) capable of moving within a cyclophane 11, as a needle through a buttonhole (Figure 12). The interaction between the two systems is measured on the fluorescence emitted by the pyridinium salt free cyclophane. The azobenzene trans-10 is conveniently replaced with electron donor units, so that when it is associated, as azo-10.11, the fluorescence is completely inhibited by charge-transfer interactions. The photoexcitation carried out by irradiation with light of $\lambda=$ $360 \mathrm{~nm}$ of a solution of trans-10 and $\mathbf{1 1}$ causes a process of "unthreading". The cis isomer $\mathbf{1 0}$ has a much weaker interaction with cyclophane $\mathbf{1 1}$, and this fact is reflected in the large increase in fluorescence intensity of $\mathbf{1 1}$. The trans-isomer $\mathbf{1 0}$ is regenerated when the mixture is left in the dark or irradiated with light of $\lambda=440 \mathrm{~nm}$, and as a result becomes a "thread" in the cyclophane. In this way, the isomerization of the $\mathrm{N}=\mathrm{N}$ double-bond type triggers a movement of threading/unthreading exclusively governed by light.

\section{Molecular scissors}

In 2003, Aida's group described a new generation of optical molecular devices composed of different kinds of organic systems interconnected through an azobenzene unit as the epicentre of the motion. First, a molecular switch was synthesized capable of making a motion similar to the opening and closing of scissors. This switch consists of a central unit of 1,1',3,3'-tetrasubstituted ferrocene, two phenyl groups as scissor blades and two phenylethylene groups as handles linked through an azobenzene [117,118]. The light irradiation of $\lambda=$ $350 \mathrm{~nm}$ (180 min) leads to a mixture of isomers trans/cis 11:89, while exposure to visible light $(\lambda>400 \mathrm{~nm}, 15 \mathrm{~min})$ again enriches $46 \%$ of the trans isomer. The molecular motion was studied by circular dichroism (CD), ${ }^{1} \mathrm{H}$ NMR and DFT calculations confirming that the change in the configuration of the $\mathrm{N}=\mathrm{N}$ double bond modifies the initial position of the ferrocene resulting in an opening (cis) and closing (trans) of the "blades" of the phenyl group (Figure 13). The angle between the two phenyl groups is altered from about $9^{\circ}$ upon closing of the "scissors" (trans-12) to more than $58^{\circ}$ when it opens (cis-12).

\section{Molecular pedals}

In 2006 [119,120], the same authors described a more complex system that included two terminal units of porphyrin-Zn noncovalently associated to a host molecule of bis-isoquinoline $\mathbf{1 3}$ (Figure 14). The exposure of azo derivative 13 to light of $\lambda=$ $350 \pm 10 \mathrm{~nm}$ leads to a mixture of isomers trans/cis 22:78. Irradiation of this mixture of isomers at $\lambda>420 \mathrm{~nm}$ returns the system to an enrichment of the trans isomer (63\%).

The study of the photoisomerization process of $\mathbf{1 3}$ revealed that the configurational change of the azobenzene unit causes a sequence of molecular motions of the units connected to it. The

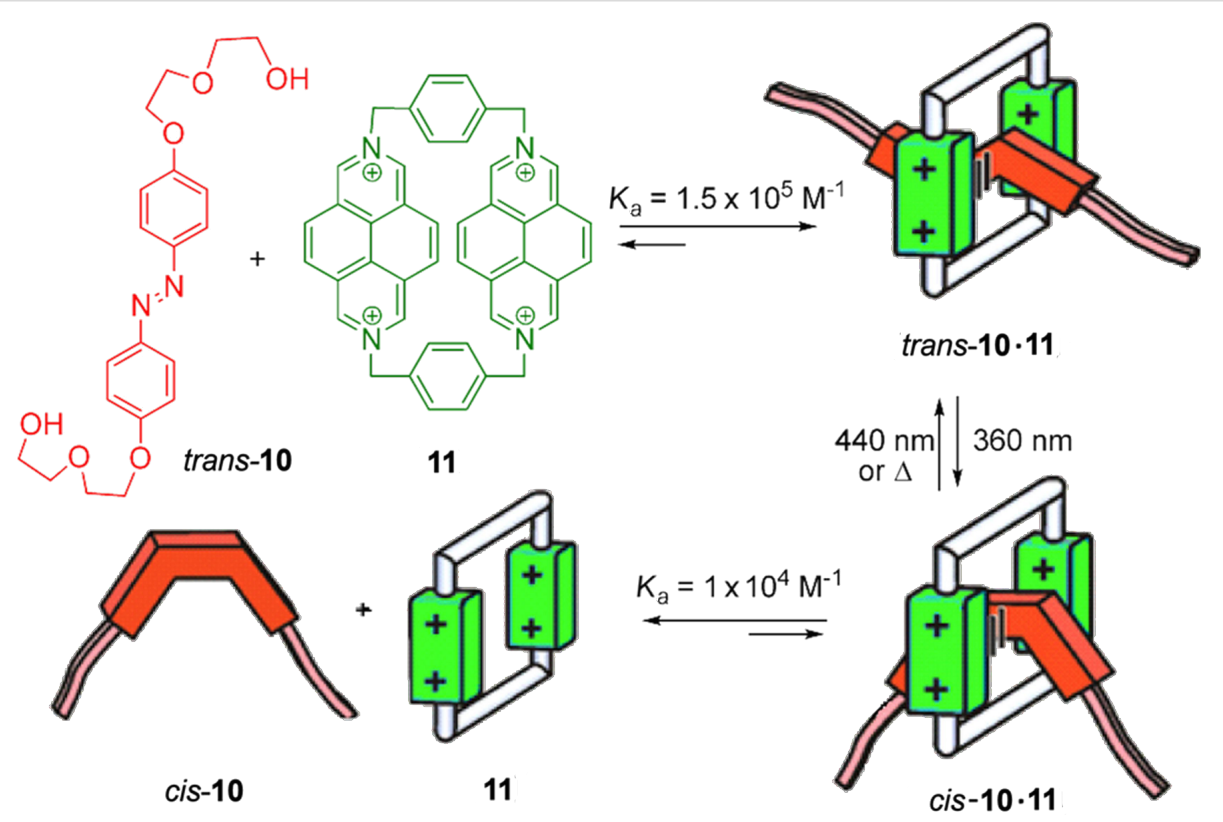

Figure 12: Molecular threader. Reprinted (adapted) with permission from Acc. Chem. Res. 2001, 34, 445-455. Copyright (2001) American Chemical Society. 


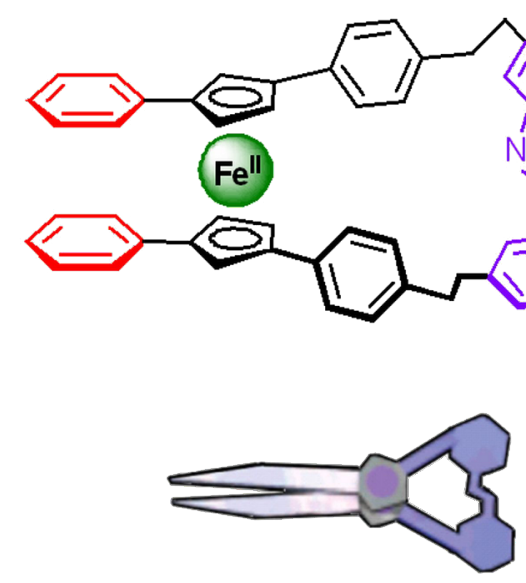

trans-12

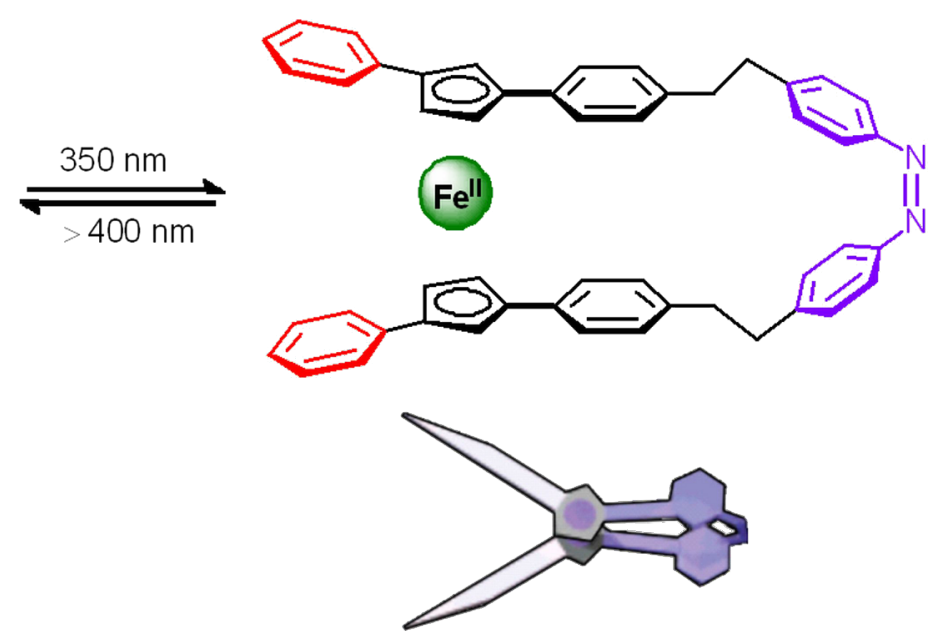

cis-12

Figure 13: Molecular scissors based on azobenzene 12. Reprinted (adapted) with permission from J. Am. Chem. Soc. 2003, 125, 5612-5613. Copyright (2003) American Chemical Society.

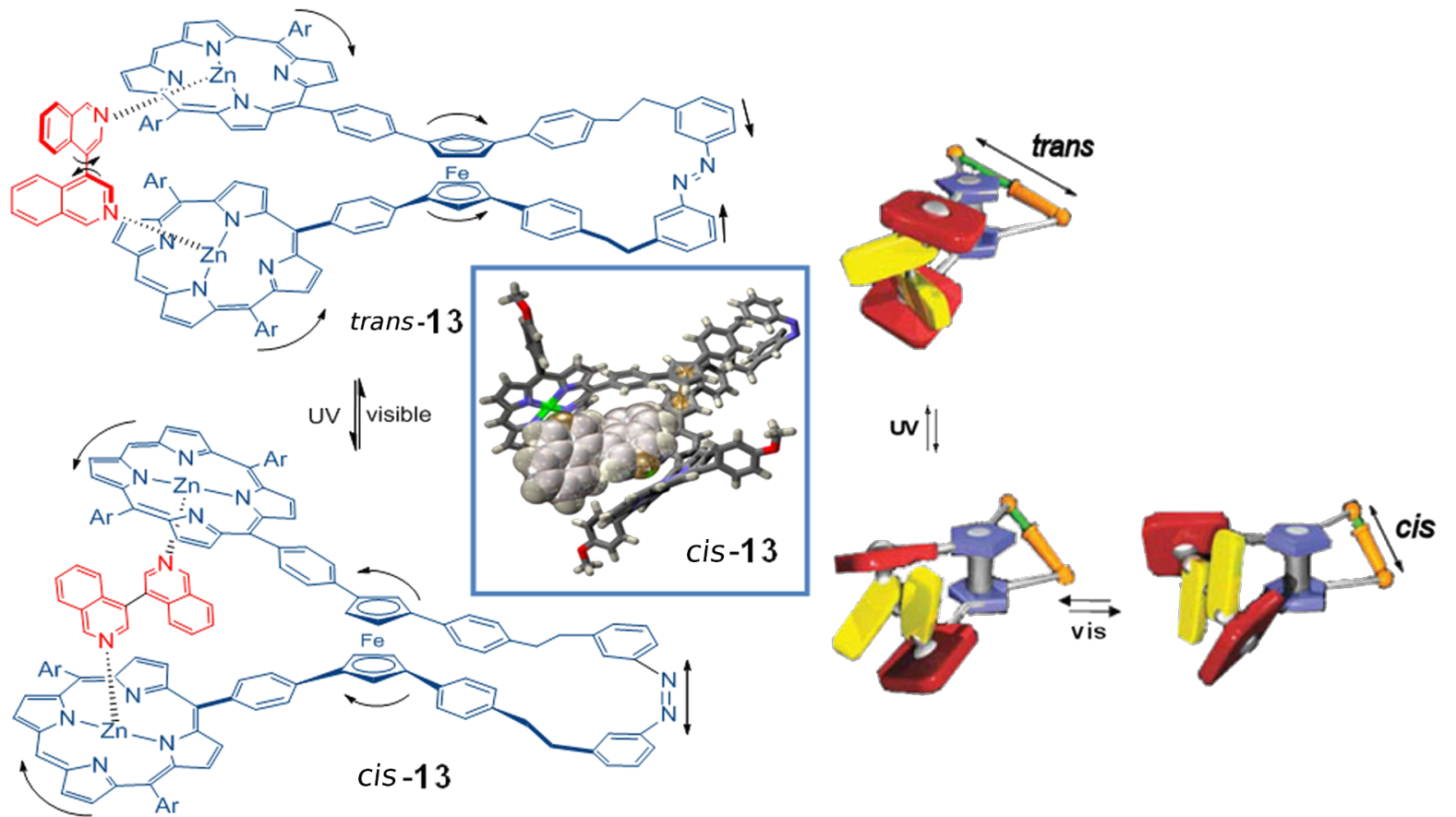

Figure 14: Molecular pedals. Reprinted by permission from Macmillan Publishers Ltd: Nature, 2006, 440, 512-515, copyright (2006).

ferrocene unit rapidly responds by turning, which in turn induces an opening motion that distances the porphyrin units, causing a mechanical spin rotation in the bis-isoquinoline molecule similar to a pedal. This device is effective if the porphyrin- $\mathrm{Zn}$ and bis-isoquinoline units remain associated during the photoisomerization, i.e., the dynamics of dissociation between these units is slower than the photoinduced movement itself. In this case, the dissociation constant is six orders of magnitude slower than the trans-cis photoisomerization, which ensures that the bis-isoquinoline unit is coordinated to azocompound $\mathbf{1 3}$ during the isomerization process of the azobenzene unit.

\section{Nanovehicle}

One proposed mechanism for the isomerization of azobenzene suggests that photoinduced trans-cis isomerization passes 
through a rotating mechanism, while the thermal cis-trans reisomerization follows an inversion mechanism [121]. The combination of both processes (photochemical and thermal) could lead to opening (trans) and closing (cis) mechanical motion accompanied by a translational motion. Based on this mechanistic hypothesis, Tour et al. created a branched azobenzene structure to realize a nanovehicle able to move like a caterpillar (Figure 15) [122,123].

The system consists of three parts: A central azobenzene, a rigid frame composed of oligo(phenylacetylenes), which in turn are anchored to azobenzene through para positions, and wheels based on fullerene $\mathrm{C}_{60}$ (azo-14) or $p$-carboranes (azo-15). Photoisomerization studies suggest that only the azobenzene system with $p$-carborane wheels (azo-15) may be useful as a molecular switch, because the photoisomerization of azofullerene $\mathbf{1 4}$ leads to only $8 \%$ of the cis-isomer. Although, the quantum yield obtained for cis-14 is not very high, this proportion is significant, given the speed with which energy transfer to the fullerene unit occurs [124]. In the case of azo- $p$-carborane 15 , irradiation at $\lambda=365 \mathrm{~nm}$ for 10 min leads to $24 \%$ of the cis isomer. The photochemical $(\lambda>495 \mathrm{~nm}, 5 \mathrm{~min})$ or thermal (heating to $40{ }^{\circ} \mathrm{C}, 15 \mathrm{~min}$ ) reisomerization recovers the initial state. After these preliminary results it remains to be demon- strated whether the molecular motion of the device $\mathbf{1 5}$ achieves the expectations of the authors, to prove the usefulness of the device.

\section{Molecular driving force}

One of the more attractive and interesting applications of the isomerization processes of azobenzenes is their use as nanoimpeller-controlled drug release devices. The idea is to anchor a functionalized azobenzene inside the silica nanoparticle, thereby forming light-activated mesostructured silica nanoparticles. The azobenzene $\mathbf{1 6}$ is anchored to the particle wall while the other extreme is free (Figure 16) [125-127].

These nanoparticles have pores capable of holding other molecules. The isomerization process of azobenzene generates a molecular flapping and the molecules can be expelled outside in a photoinduced way. The morphology of the light-activated mesostructured silica nanoparticles (LAMs) is evaluated by scanning electron microscopy (SEM), electronic transmission images (TEM), UV-vis and X-ray analysis, setting a pore diameter of $1.9 \pm 0.1 \mathrm{~nm}$, a volume of $0.248 \mathrm{~cm}^{-3} \cdot \mathrm{g}^{-1}$ and a surface area of $621.19 \mathrm{~m}^{2} \cdot \mathrm{g}^{-1}$. The nanoparticles, which contain $2.4 \%$ by weight of azobenzene, are treated with camptothecin (CPT), a drug used in the treatment of cancer, which is housed inside.

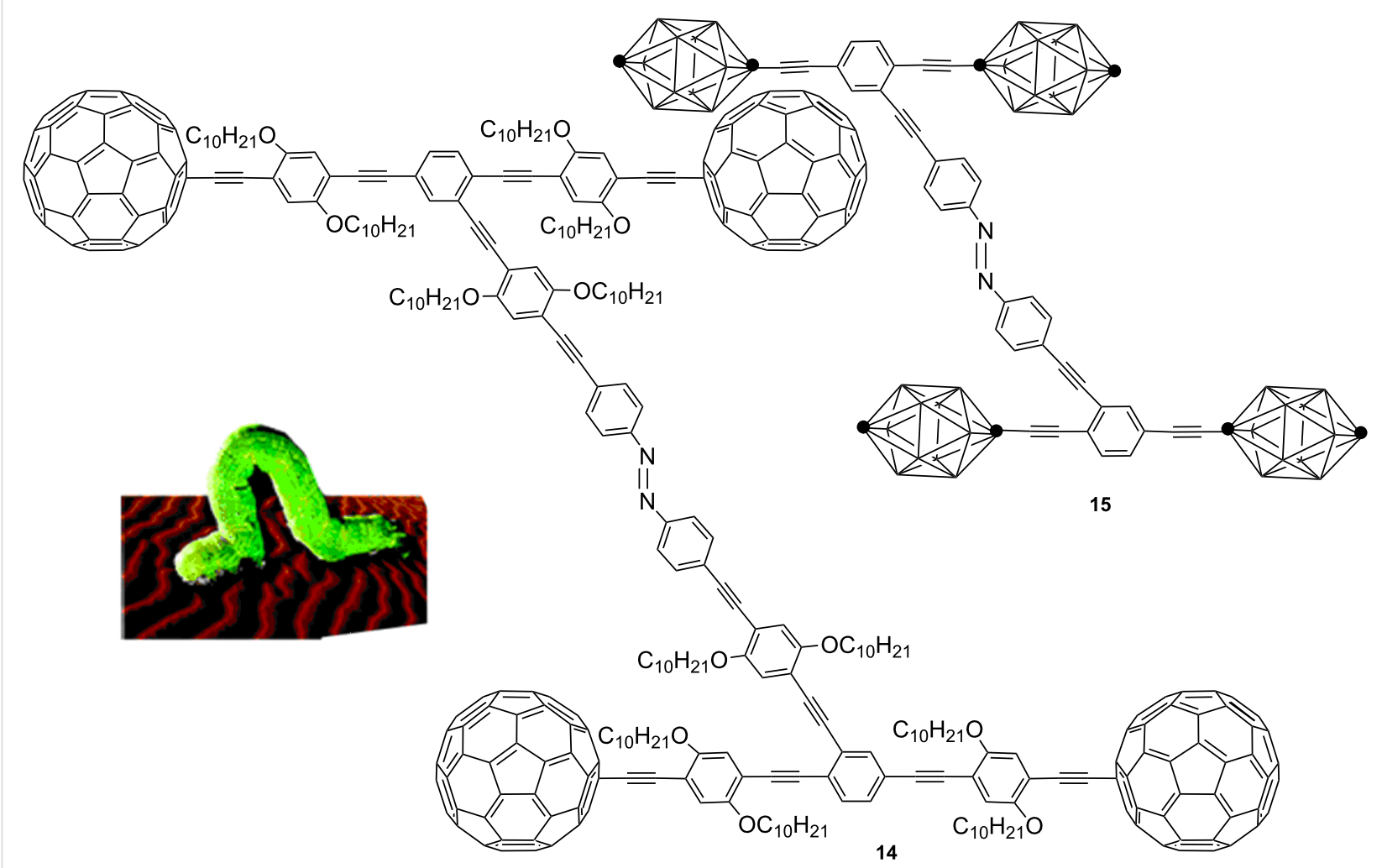

Figure 15: Design of nanovehicles based on azo structures. Reprinted (adapted) with permission from Org. Lett. 2008, 10, 897-900. Copyright (2008) American Chemical Society. 


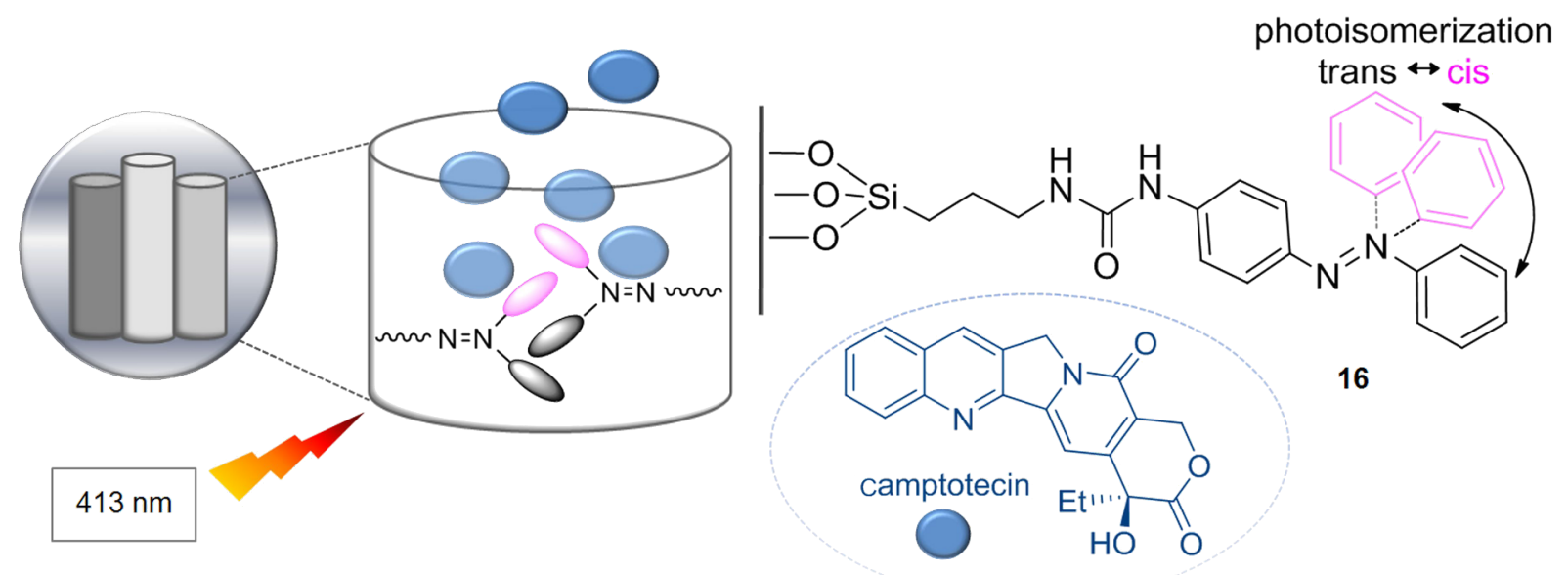

Figure 16: Light-activated mesostructured silica nanoparticles (LAMs).

The LAMs (CPT) were incubated for $3 \mathrm{~h}$ with cancer cells in darkness. These cells are irradiated for $5 \mathrm{~min}$ at $0.1 \mathrm{~W} \cdot \mathrm{cm}^{-2}$ at $\lambda=413 \mathrm{~nm}$, where both isomers have the same extinction coefficient promoting a continuous exchange between both trans-cis isomers, and then they were incubated again in the dark for 48 hours. This experiment shows that the azobenzene units located within the LAMs (CPT) act as promoters (Figure 16), releasing the drug (CPT) only after irradiation of the nanoparticle with a light at a certain wavelength, hence resulting in cell death. The number of released molecules can be controlled depending of the light intensity and irradiation time. On the other hand, the camptothecin, in the absence of light, stays inside the nanoparticles and the cells remain intact. Control experiments with cells lacking the nanoparticles revealed that irradiation at $413 \mathrm{~nm}$ does not affect cell survival, and similarly irradiation of incubated cells with LAMs not containing CPT, did not lead to cell death, thus confirming the biocompatibility of the LAMs with the cells.

\section{Molecular lift}

The individual molecular motion of azobenzene in the cis-trans isomerization process can be amplified when the azobenzene is anchored to a more complex system [128]. The cooperative combination of each individual photoisomerization can increase the dynamic response if the azobenzenes are self-assembling, generating an uniform motion [129]. An illustrative example is given in Figure 17, in this case one of the azobenzene rings has a $p$-mercaptophenyl group through which it is associated with an $\mathrm{Au}(111)$ layer [130]. All the azobenzenes are oriented and form self-assembled monolayers (SAMs). The trans-cis isomerization process of the azobenzene unit placed in the metal layer takes place with excellent yield (88-98\% cis isomer). This is particularly relevant for future applications in the design of devices for information-storage-based photochromic systems [131]. The photo-reversal of SAMs also proceeds with excellent yield (94-100\%). The structural difference $\left(d_{\text {trans }}-d_{\text {cis }}\right)$ between both isomers is approximately $7 \AA$.
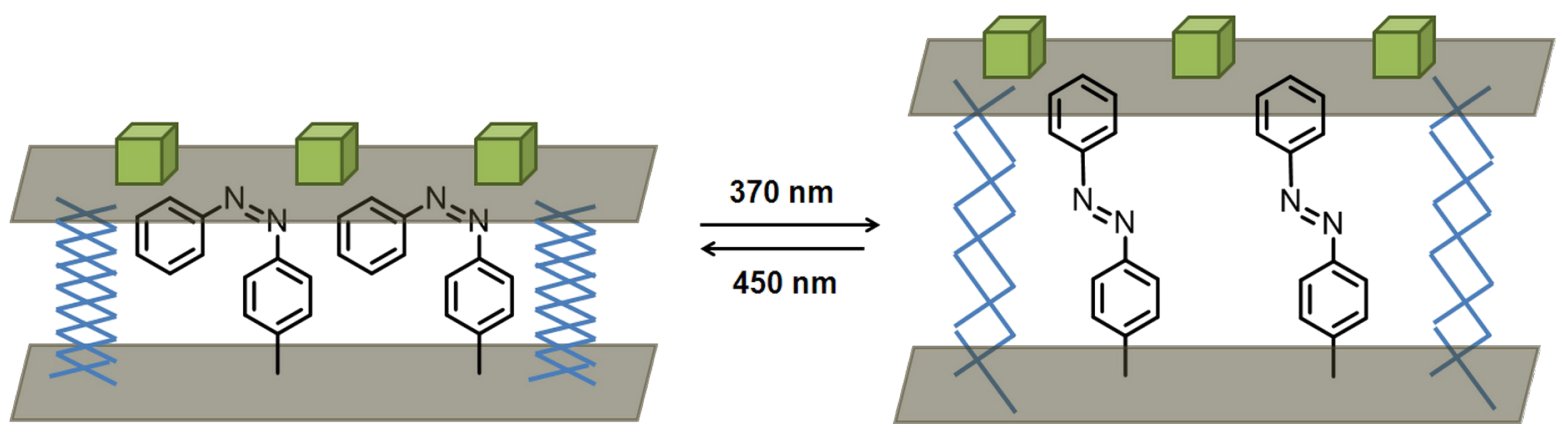

Figure 17: Molecular lift. 
By scanning tunnelling microscopy (STM), the authors determined the surface density of $\mathrm{SAM}_{\mathrm{azo}}$, and the force exerted in the photoisomerization molecular motion of all the azobenzenes in the $\mathrm{SAM}_{\mathrm{azo}}$ was calculated. The individual photomovement of each azobenzene results in a collective structural change in a certain direction. This cooperative molecular motion of $\mathrm{SAM}_{\mathrm{azo}}$ acts as a molecular lift capable of lifting one $\mathrm{Hg}$ drop deposited on the monolayer of azobenzenes. Furthermore, this device acts as a photoswitch of the current between the $\mathrm{Au}(111)$ layer and the $\mathrm{Hg}$ drop. A significant increase of the current density of about one order of magnitude occurs under irradiation at $\lambda=370 \mathrm{~nm}$, and the corresponding decrease is produced in a reversible way when the azobenzene is irradiated at $\lambda=450 \mathrm{~nm}$.

\section{Molecular sunflower}

When an azobenzene is differently substituted in the ortho or meta positions, the corresponding trans and cis isomers can adopt different conformations. A simple example is illustrated in Figure 18 for mono-ortho-substituted azobenzene. In the trans isomer, the azo group is oriented as far as possible away from the substituent in the ortho position (trans-I form), or placed next to it (trans-II). Similarly, motion of the aromatic rings accompanying the photoisomerization process can also lead to several cis conformers (cis-I and cis-II). The electronic nature and steric bulk of the substituents of the aromatic rings can be a key factor in favouring one type of conformation in the azocompounds. Considering the relationship between the molecular conformation and biological recognition, it is particularly interesting to design azo devices that allow control, by an external stimulus, of the configuration of the $\mathrm{N}=\mathrm{N}$ double bond, and also to define a specific orientation or conformation of each stereoisomer (trans or cis).

Recently, Carreño et al. [132,133] synthesized different enantiomerically pure sulfinyl azobenzenes. The sulfinyl group is a key component in the design of a molecular sunflower, a device that by means of light can undergo phototropism with a given direction. The enantiomerically pure 2- and 3-sulfinyl azo compounds are obtained with excellent regioselectivities by using a new and simple method for the synthesis of aromatic azobenzenes based on the treatment of quinone bisacetals $\mathbf{1 7}$ and 19 with different arylhydrazines 18 [134]. In both cases, the sulfoxide group preferentially adopts a rigid S-cis conformation [135], situating the sulfinylic oxygen in 1,3-parallel arrangement with the neighbouring hydrogen (blue arrow, Scheme 1). This arrangement is essential to force a specific final conformation of the azocompound.

Irradiation with light of $\lambda=365 \mathrm{~nm}$ results in $33-75 \%$ of cisisomer 20 and $84-99 \%$ of $c i s-\mathbf{2 1}$. The photochemical reisomerization $(\lambda=436 \mathrm{~nm})$ recovers the initial state in both sets of sulfinyl derivatives. The study of the photochromic properties of enantiopure azocompounds $\mathbf{2 0}$ and $\mathbf{2 1}$ by using standard techniques (UV-vis, circular dichroism, chiral HPLC and NMR) has established that the chiral optical response differs greatly depending on the position of the sulfoxide group (C-2 or $\mathrm{C}$-3). Cis isomers in both $p$-tolylsulfinyl azocompounds show an opposite arrangement of substituents around the $\mathrm{N}=\mathrm{N}$ group, with an S-shaped structure for cis-20 or a U-shaped structure for cis-21. The conformational rigidity of the chiral sulfinyl group is the key to controlling the directionality of the molecular

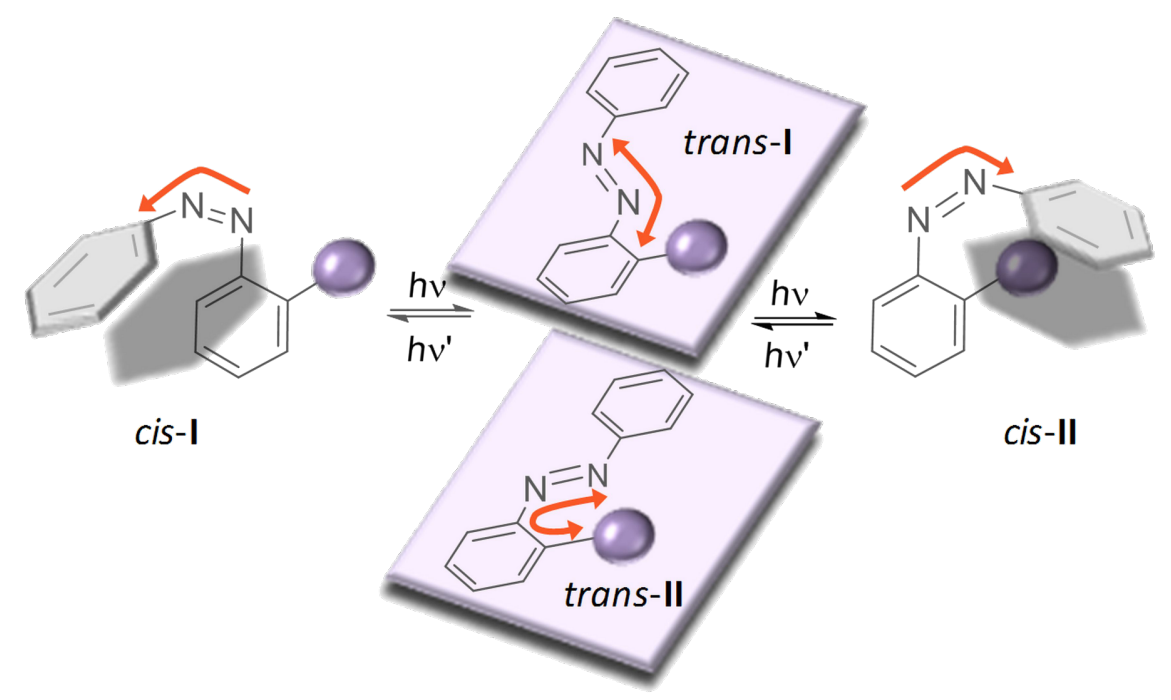

Figure 18: Conformational considerations in mono-ortho-substituted azobenzenes. 

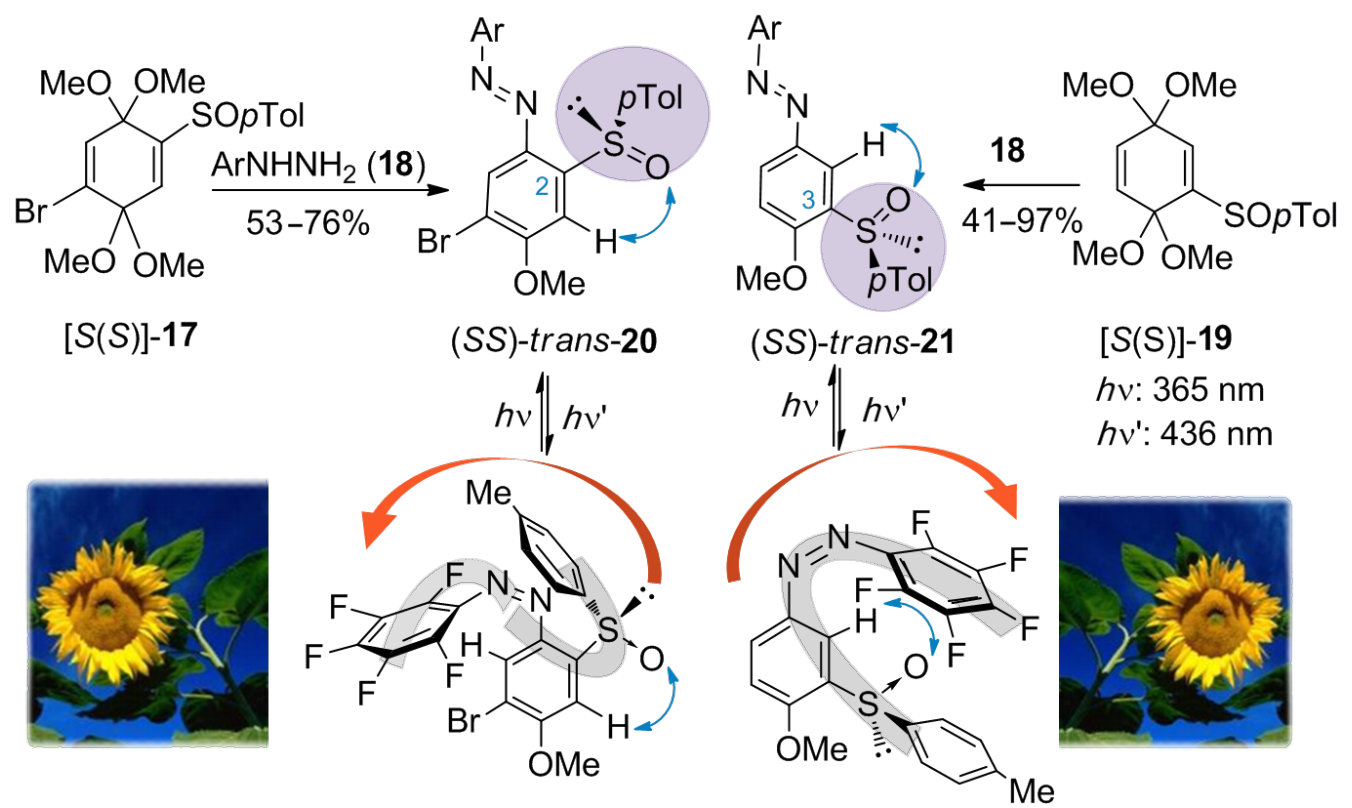

\section{$[S(S)]-19$}

$h v: 365 \mathrm{~nm}$

$h v^{\prime}: 436 \mathrm{~nm}$

(SS)-cis-20, form-S

(SS)-cis-21, form-U

Scheme 1: Synthesis and photoisomerization of sulfinyl azobenzenes. Reprinted (adapted) with permission from J. Am. Chem. Soc. 2007, 129, 7089-7100. Copyright (2007) American Chemical Society.

motion of photoisomerization. Thus, choosing the position of the sulfoxide group in the azobenzene (ortho or meta to $\mathrm{N}=\mathrm{N}$ ) by irradiation with light causes a determined geometric, conformational and rigid change, inducing a specific phototropism as in the stem of a sunflower.

\section{Photoactive Brønsted base}

The conformation of a molecule can have direct implications for its reactivity. Thus, the control of the conformation is the key to controlling its reactivity. The union of this concept with molecular switches has opened the door to the development of new photoreactive compounds in which the reactivity can be controlled by an external stimulus as a switch (on/off).
Recently, Hecht et al. [136,137] designed a Brønsted base whose $\mathrm{p} K_{\mathrm{a}}$ changes with light. The study focuses on the azobenzene 22, which possesses, in an aromatic ring, a spirocyclic lactone fused to a conformationally restricted piperidine (Figure 19).

In the structure of the trans isomer 22, the pair of unshared electrons of nitrogen is inaccessible. The trans-cis photoisomerization process changes the disposition of the aromatic rings, unlocking access to the basic center of the piperidine. This switch, of Brønsted base type, has been tested in the Henry reaction between $p$-nitrobenzaldehyde and nitroethane ensuring that only the cis isomer is able to catalyze the reaction.
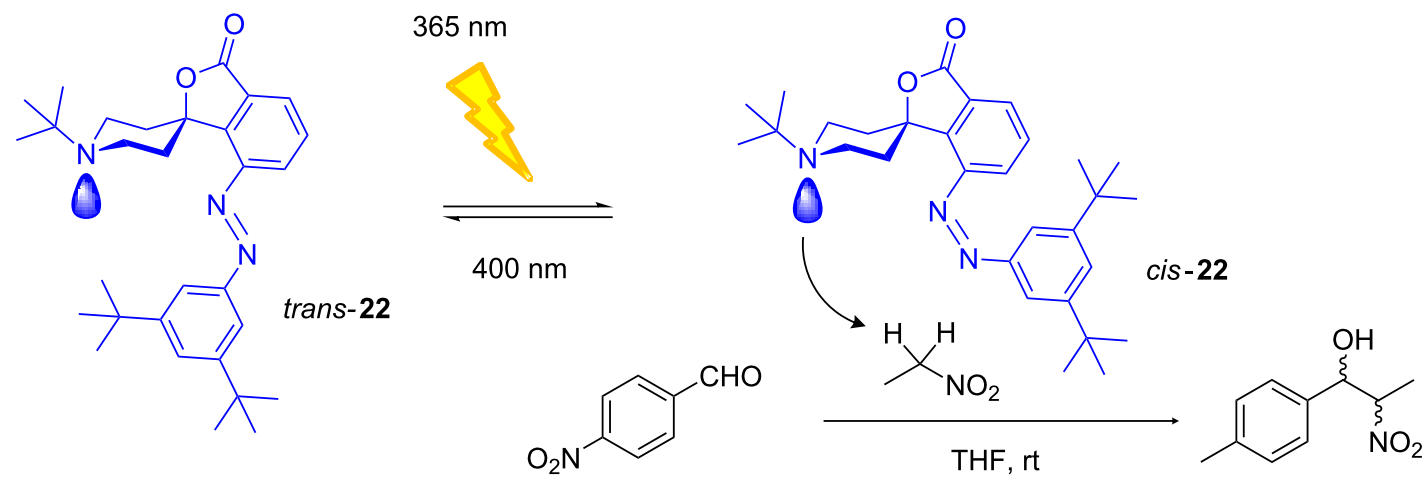

Figure 19: Photoisomerization of azocompound 22 and its application as a photobase catalyst. 


\section{Photodirected azo polymers}

A spectacular example of the molecular motion of photoisomerization is shown in Figure 20. The irradiation of polymers containing light-sensitive molecules such as azobenzenes can lead to a photocontraction of the polymer, converting luminescent energy to mechanical energy. Ikeda et al. [37] demonstrated how the irradiation of a liquid-crystal elastomer (LCE) of azobenzenes with linearly polarized light is able to collapse and expand the LCE films (yellow sheet in Figure 20) in a certain direction.

The film is obtained by thermal polymerization of the azocompound 23 (monomer), by using the diacrylate derivative $\mathbf{2 4}$ as a crosslinking agent. The azo-LCEs comprise a polydomain with the characteristics of a liquid crystal, formed by many microsized domains of azobenzene aligned in the same direction. Although macroscopically the direction of alignment is random, under irradiation with linearly polarized light the selective absorption of the light by the azobenzene causes a collective management of all microdomains, such that the orientation of the fold is governed by the direction of the linearly polarized light source (white arrow in Figure 20). The consecutive irradiation with $\lambda=366 \mathrm{~nm}$ at $0^{\circ},-45^{\circ},-90^{\circ}$ or $-135^{\circ}$ following by irradiation at $\lambda=540 \mathrm{~nm}$ produces the contraction and expansion of the film in the clockwise direction. Recently, this liquidcrystal elastomer was used in developing the first plastic photomechanical motor capable of converting light into mechanical energy without any battery or power source [47].

\section{Bistable memory device}

Recently, Stoddart and Venturi's group described a molecular switch using a [2] rotaxane 25, which undergoes mechanical movements triggered by redox processes and can be switched between two thermodynamically stable conformations [138]. The energy barriers between these conformations can be controlled kinetically by photochemical modulation. The ring component of the [2] rotaxane is cyclobis(paraquat-p-phenylene) and the dumbbell is comprised of a tetrathiafulvalene unit and a
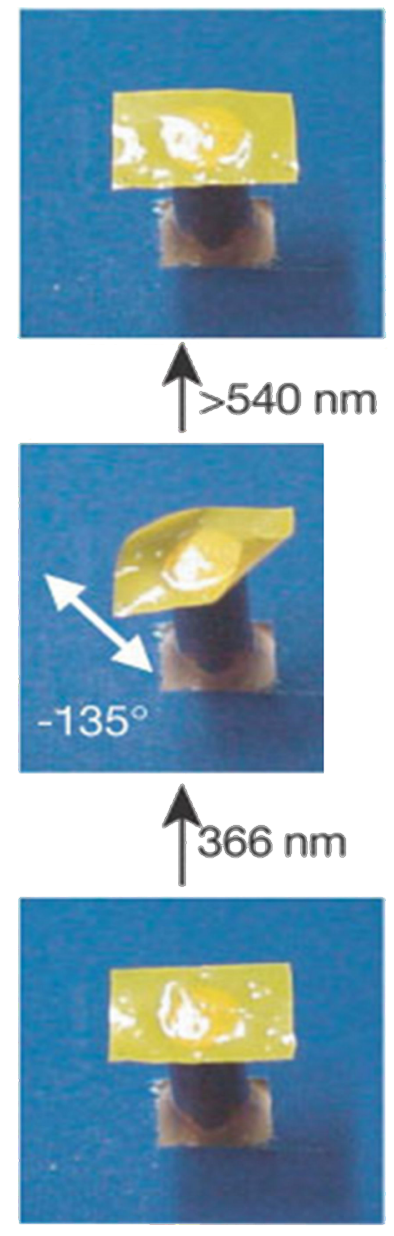
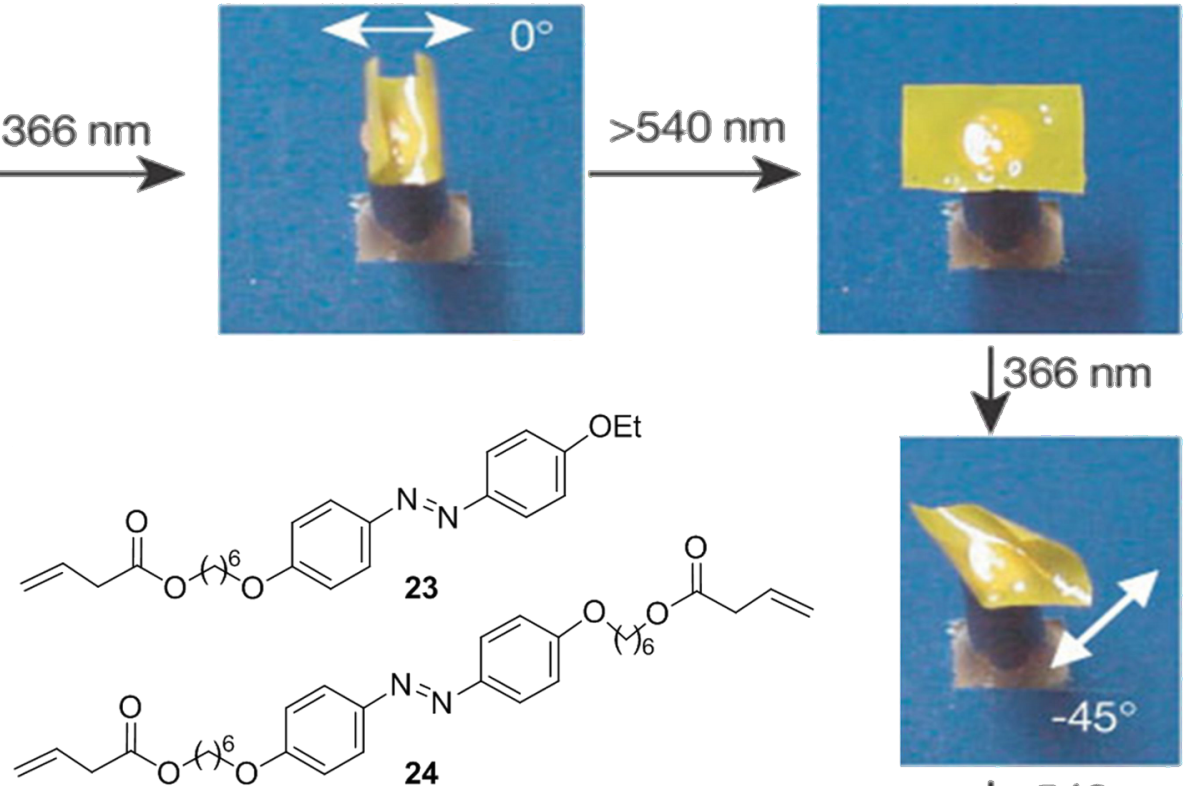

24
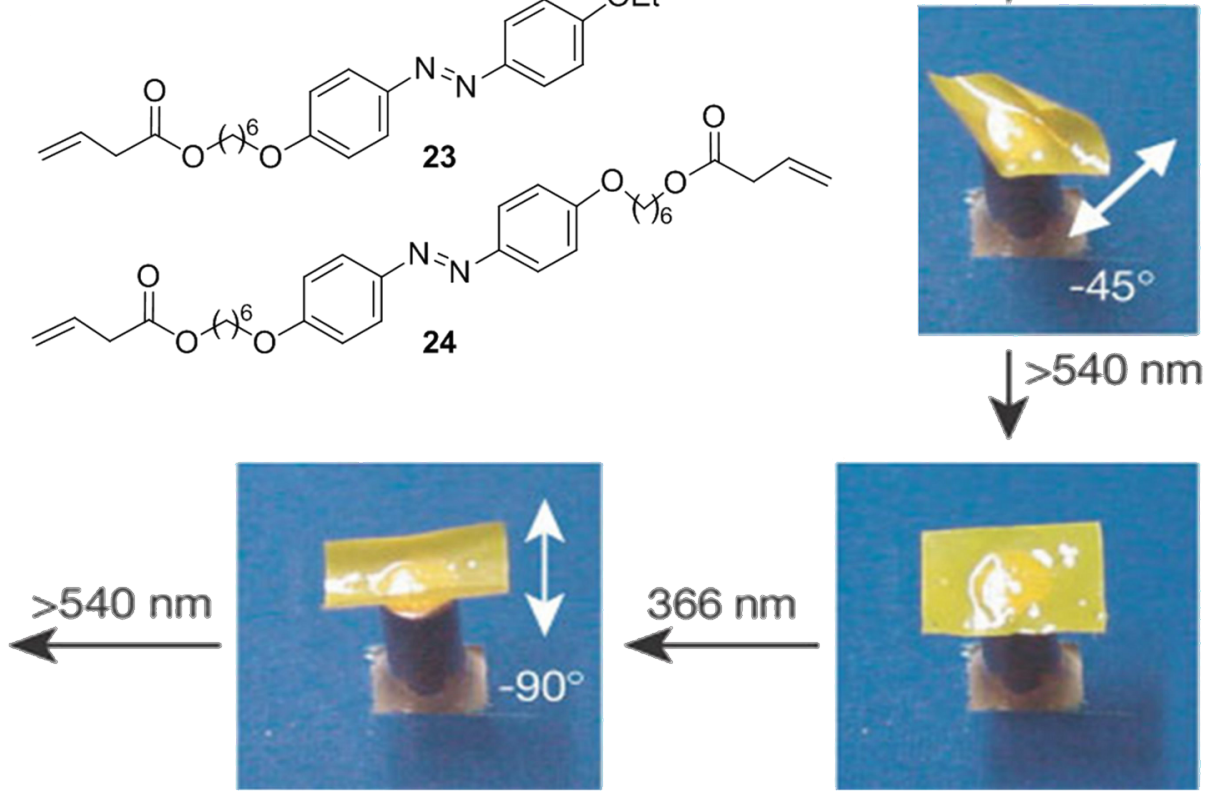

Figure 20: Effect of irradiation with linearly polarized light on azo-LCEs. Reprinted by permission from Macmillan Publishers Ltd: Nature, 2003, 425, 145-146, copyright (2003). 
1,5-dioxynaphthalene as $\pi$-electron-donating recognition sites, and a photoactive unit of 3,5,3',5'-tetramethylazobenzene, which by irradiation of light can be switched between its cis and trans conformations (Figure 21). Probably, this structure is a good candidate for use in the design of engineered test devices. Data can be written on the rotaxane when the units of tetrathiafulvalene are oxidized and then blocked in the trans-cis photoisomerization process, on the azobenzene fragment. After writing the information, the oxidized species can be reduced to the original form without loss of data. The data is stored until irradiation of the azobenzene fragment allows the reopening of the azobenzene gate.

\section{Unidirectional photoisomerization}

The process, trans to cis isomerization, generates helicoidal chirality, such that the isomer can adopt a helicoidal geometry with $P$ or $M$ chirality. The configurational stability of $c i s-$ azobenzenes depends of the interconversion barrier between the cis- $(P)$ and cis- $(M)$ isomers. The size and the electronic nature of the substituents present in the systems are the factors that are more influential on the energetic barrier. Haberhauer et al. described the unidirectional photoisomerization process of azobenzene 26 [139]. The irradiation with light of the achiral trans isomer gives rise to the cis isomer with $P$ helicity. A chiral clamp was synthesized, by anchoring a chiral cyclic imidazole peptide to both aromatic rings of azobenzene. The system is flexible enough to allow the isomerization between the trans and cis isomer but in turn destabilizes one of the helices of the cis isomer, and only one cis isomer $(P)$ is present in solution (Figure 22).

\section{Conclusion}

Azobenzene is one of the most used systems in the design of molecular photoswitches. The synthesis is very easy and their photochromic properties are very interesting. An external stimulus, normally light irradiation at a certain wavelength, causes a fluctuation between the cis-trans isomeric species. This isomerization is reversible, photochemically and thermally. The molecular motion that occurs in the isomerization process has facilitated the development of molecular devices. Today, researchers

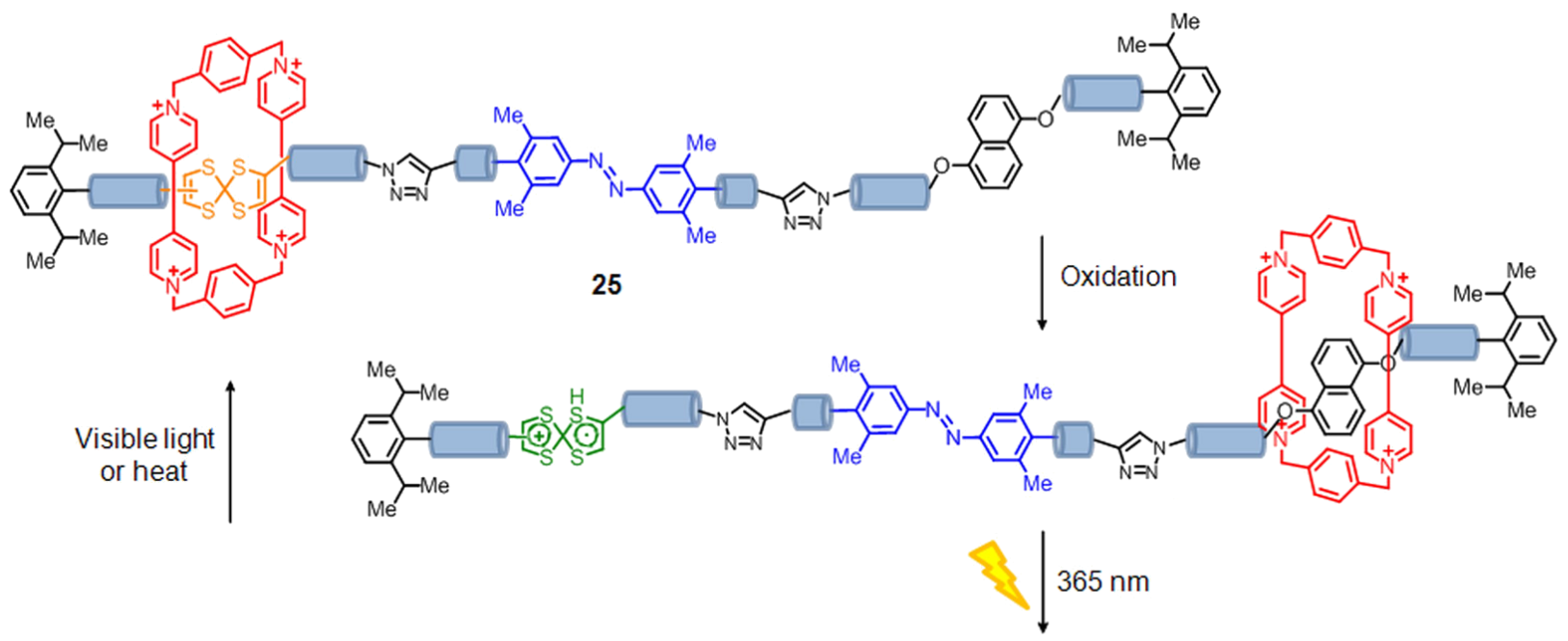
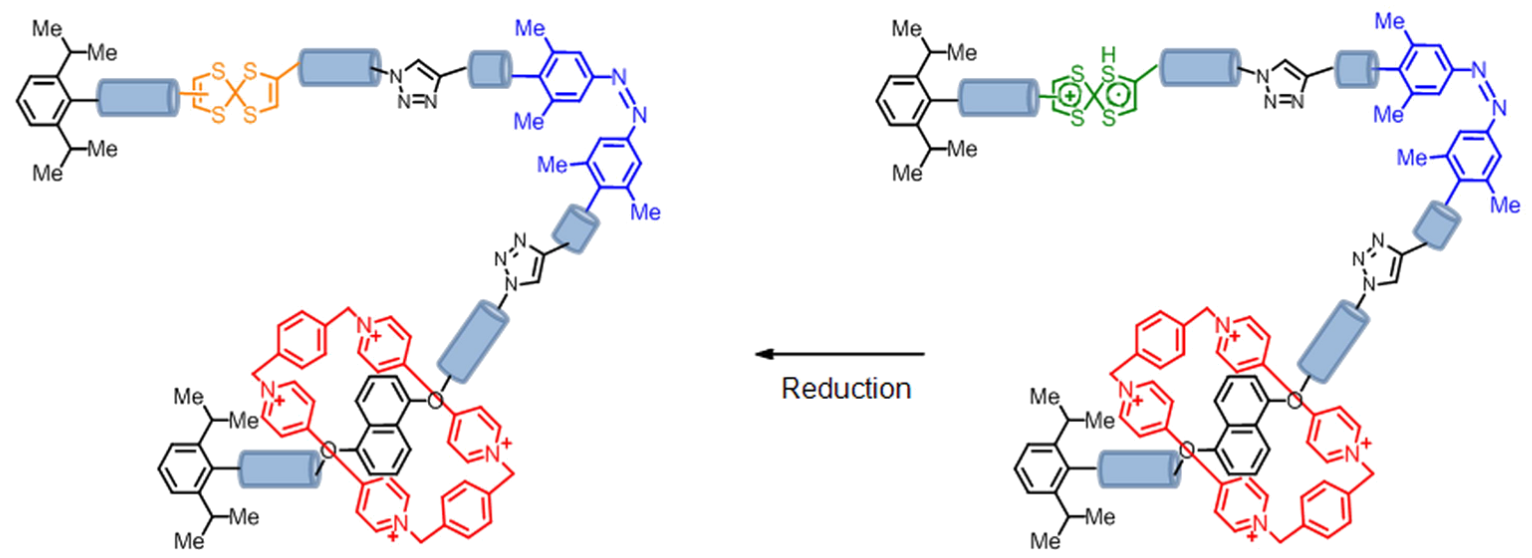

Figure 21: Chemically and photochemically triggered memory switching cycle of the [2]rotaxane 25. 
<smiles>[R]C1([R])Cc2cccc(c2)CC([R])([R])N=Nc2cccc(c2)C1</smiles>

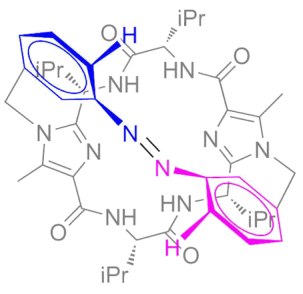

cis- $(P)-26$
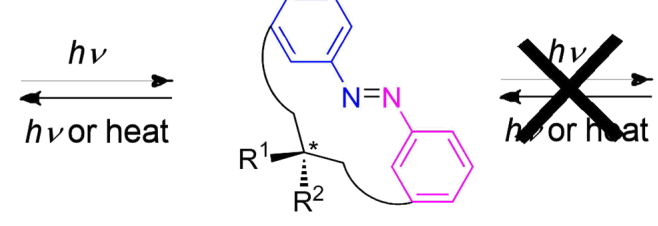<smiles></smiles>
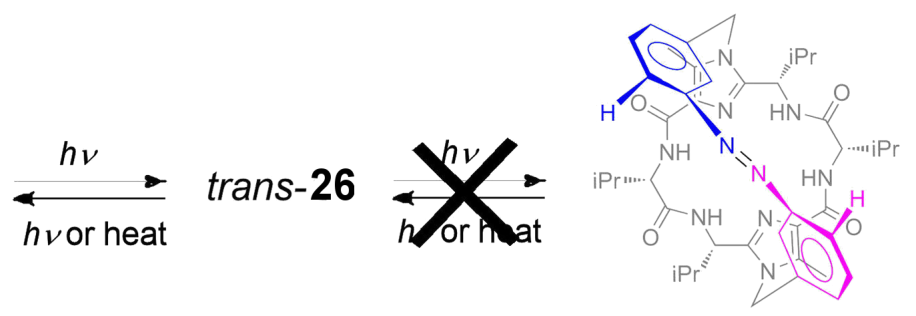

cis- $(M)-26$

Figure 22: Unidirectional photoisomerization process of the azobenzene 26.

continue to develop synthetic supplements to improve the properties of azobenzenes towards the development of more efficient devices that control the isomerization and orientation of the azobenzene, shifting the photoisomerization process to other concepts of chemistry, from the development of photoreactive compounds or photomechanical materials and even bioincorporation of azobenzenes, to more complex systems that allow a greater understanding, such as the photocontrol of biological dynamic mechanisms.

\section{Acknowledgements}

E.M. thanks Ministerio de Ciencia y Innovación for a contract of "Junta de Ampliación de Estudios" programm (JAEDoc). Financial supports by Ministerio de Ciencia e Innovación (Consolider-Ingenio 2009 (MULTICAT project), MAT201129020-C02 and CTQ2011-24783) and European Social Fund (Grant SOLGEMAC-S2009/ENE-1617) are acknowledged.

\section{References}

1. Ribagorda, M.; Merino, E. An. Quim. 2009, 105, 290-299.

2. Mitscherlich, E. Ann. Pharm. 1834, 12, 311-314. doi:10.1002/jlac.18340120282

3. Hartley, G. S. Nature 1937, 140, 281-282. doi:10.1038/140281a0

4. Zollinger, H. Color Chemistry. Syntheses, Properties, and Applications of Organic Dyes and Pigments, 3rd ed.; Wiley-VCH: Weinheim, Germany, 2003.

5. Hunger, K. Industrial Dyes: Chemistry, Properties and Applications; Wiley-VCH: Weinheim, Germany, 2003; pp 14-35.

6. Zollinger, H. Azo and Diazo Chemistry; Interscience: New York, 1961.

7. Ross, D. L.; Blanc, J. Photochromism by cis-trans Isomerization. In Photochromism; Brown, G. H., Ed.; Wiley-Interscience: New York, 1971; pp 471-556.

8. Kumar, G. S.; Neckers, D. C. Chem. Rev. 1989, 89, 1915-1925. doi:10.1021/cr00098a012
9. Rau, H. Photoisomerization of Azobenzenes. In Photochemistry and Photophysics; Rabek, J. F., Ed.; CRC Press: Boca Raton, FL, USA, 1990; Vol. 2, pp 119-142.

10. Rau, H. Angew. Chem., Int. Ed. Engl. 1973, 12, 224-235. doi:10.1002/anie.197302241

11. Brown, E. V.; Granneman, G. R. J. Am. Chem. Soc. 1975, 97 , 621-627. doi:10.1021/ja00836a025

12. Rau, H. Azo Compounds. In Photochromism, Molecules and Systems; Dürr, H.; Bouas-Laurent, H., Eds.; Elsevier: Amsterdam, 2003; Vol. 1, pp 165-192.

13. Suginome, $\mathrm{H}$. In CRC Handbook of Organic Photochemistry and Photobiology; Horspool, W. M.; Song, P.-S., Eds.; CRC Press: Boca Raton, FL, USA, 1995; p 824.

14. Morgenstern, K. Acc. Chem. Res. 2009, 42, 213-223. doi:10.1021/ar800021q

15. Henzl, J.; Mehlhorn, M.; Gawronski, H.; Rieder, K.-H.; Morgenstern, K. Angew. Chem., Int. Ed. 2006, 45, 603-606. doi:10.1002/anie.200502229

16. Choi, B.-Y.; Kahng, S.-J.; Kim, S.; Kim, H.; Kim, H. W.; Song, Y. J.; Ihm, J.; Kuk, Y. Phys. Rev. Lett. 2006, 96, 156106. doi:10.1103/PhysRevLett.96.156106

17. Koshima, H.; Ojima, N.; Uchimoto, H. J. Am. Chem. Soc. 2009, 131, 6890-6891. doi:10.1021/ja8098596

18. Sension, R. J.; Repinec, S. T.; Szarka, A. Z.; Hochstrasser, R. M. J. Chem. Phys. 1993, 98, 6291-6315. doi:10.1063/1.464824

19. Nägele, T.; Hoche, R.; Zinth, W.; Wachtveitl, J. Chem. Phys. Lett. 1997, 272, 489-495. doi:10.1016/S0009-2614(97)00531-9

20. Dhammika Bandara, H. M.; Burdette, S. C. Chem. Soc. Rev. 2012, 41, 1809-1825. doi:10.1039/c1cs15179g

21. Bortolus, P.; Monti, S. J. Phys. Chem. 1979, 83, 648-652. doi:10.1021/j100469a002

22. Rodier, J. M.; Myers, A. B. J. Am. Chem. Soc. 1993, 115, 10791-10795. doi:10.1021/ja00076a041

23. Tamai, N.; Miyasaka, H. Chem. Rev. 2000, 100, 1875-1890. doi:10.1021/cr9800816

24. Chang, C.-W.; Lu, Y.-C.; Wang, T.-T.; Diau, E. W.-G. J. Am. Chem. Soc. 2004, 126, 10109-10118. doi:10.1021/ja049215p 
25. Gegiou, D.; Muszkat, K. A.; Fischer, E. J. Am. Chem. Soc. 1968, 90, 12-18. doi:10.1021/ja01003a003

26. Malkin, S.; Fischer, E. J. Phys. Chem. 1962, 66, 2482-2486. doi:10.1021/j100818a038

27. Asano, T.; Yano, T.; Okada, T. J. Am. Chem. Soc. 1982, 104, 4900-4904. doi:10.1021/ja00382a026

28. Marcandalli, B.; Pellicciari-Di Liddo, L.; Di Fede, C.; Bellobono, I. R. J. Chem. Soc., Perkin Trans. 2 1984, 589-593. doi:10.1039/p29840000589

29. Nishimura, N.; Tanaka, T.; Asano, M.; Sueishi, Y. J. Chem. Soc., Perkin Trans. 2 1986, 1839-1845. doi:10.1039/p29860001839

30. Shin, D. M.; Whitten, D. G. J. Am. Chem. Soc. 1988, 110, 5206-5208. doi:10.1021/ja00223a058

31. Willner, I.; Rubin, S. Angew. Chem., Int. Ed. Engl. 1996, 35, 367-385. doi:10.1002/anie.199603671

32. Carter, F. L.; Siatkowski, H.; Wohltgen, H., Eds. Molecular Electronics Devices; Elsevier: Amsterdam, 1988.

33. Balzani, V.; Scandola, F., Eds. Supramolecular Photochemistry; Ellis Horwood: New York, 1991.

34. Feringa, B. L.; Jager, W. F.; de Lange, B. Tetrahedron 1993, 49 , 8267-8310. doi:10.1016/S0040-4020(01)81913-X

35. Irie, M., Ed. Photoreactive Materials for Ultrahigh-Density Optical Memory; Elsevier: Amsterdam, 1994.

36. Yu, Y.; Nakano, M.; Ikeda, T. Nature 2003, 425, 145-146. doi:10.1038/425145a

37. Yager, K. G.; Barrett, C. J. Azobenzene Polymers as Photomechanical and Multifunctional Smart Materials. In Intelligent Materials; Shahinpoor, M.; Schneider, H.-J., Eds.; RSC Publishing: Cambridge, U.K., 2008; pp 424-446.

38. Ikeda, T.; Tsutsumi, O. Science 1995, 268, 1873-1875 doi:10.1126/science.268.5219.1873

39. Ikeda, T. J. Mater. Chem. 2003, 13, 2037-2057. doi:10.1039/b306216n

40. Shimoboji, T.; Larenas, E.; Fowler, T.; Kulkarni, S.; Hoffman, A. S.; Stayton, P. S. Proc. Natl. Acad. Sci. U. S. A. 2002, 99, 16592-16596. doi:10.1073/pnas.262427799

41. Feringa, B. L., Ed. Molecular Switches; Wiley-VCH: Weinheim, Germany, 2001.

42. Irie, M., Ed. Photochromism: Memories and Switches. Chem. Rev. 2000, 100, 1685-1890.

43. Hugel, T.; Holland, N. B.; Cattani, A.; Moroder, L.; Seitz, M.; Gaub, H. E. Science 2002, 296, 1103-1106. doi:10.1126/science.1069856

44. Balzani, V.; Credi, A.; Ferrer, B.; Silvi, S.; Venturi, M. Top. Curr. Chem. 2005, 262, 1-27. doi:10.1007/128_008

45. Kinbara, K.; Aida, T. Chem. Rev. 2005, 105, 1377-1400. doi:10.1021/cr030071r

46. Yamada, M.; Kondo, M.; Mamiya, J.; Yu, Y.; Kinoshita, M.; Barret, C. J.; Ikeda, T. Angew. Chem., Int. Ed. 2008, 47, 4986-4988. doi:10.1002/anie.200800760

47. Ichimura, K.; Oh, S.-K.; Nakagawa, M. Science 2000, 288, 1624-1626. doi:10.1126/science.288.5471.1624

48. Browne, W. R.; Pijper, D.; Pollard, M. M.; Feringa, B. L. Switching at the Nanoscale: Chiroptical Molecular Switches and Motors. In Chirality at the Nanoscale; Amabilino, D. B., Ed.; Wiley-VCH: Weinheim, Germany, 2009; pp 349-390. doi:10.1002/9783527625345.ch11

49. Merino, E. Chem. Soc. Rev. 2011, 40, 3835-3853. doi:10.1039/c0cs00183j
50. Zollinger, H. Diazo Chemistry I. Aromatic and Heteroaromatic Compounds; VCH: Weinheim, Germany, 1994.

51. Hegarty, A. F. Kinetics and mechanisms of reactions involving diazonium and diazo groups. In The Chemistry of Diazonium and Diazo Groups, Part 2; Patai, S., Ed.; Wiley: New York, 1978; pp 511-591.

52. Venkataraman, K., Ed. The Chemistry of Synthetic Dyes; Academic Press: New York, 1952; Vol. 1-7.

53. Szele, I.; Zollinger, H. Top. Curr. Chem. 1983, 112, 1-66. doi:10.1007/3-540-12396-2_5

54. Gordon, P. F.; Gregory, P. Organic Chemistry in Colour; Springer: New York, 1983; pp $95 \mathrm{ff}$.

55. Dugave, C.; Demange, L. Chem. Rev. 2003, 103, 2475-2532. doi:10.1021/cr0104375

56. El Halabieh, R. H.; Mermut, O.; Barrett, C. J. Pure Appl. Chem. 2004, 76, 1445-1465. doi:10.1351/pac200476071445

57. Natansohn, A.; Rochon, P. Chem. Rev. 2002, 102, 4139-4176. doi:10.1021/cr970155y

58. Yitzchaik, S.; Marks, T. J. Acc. Chem. Res. 1996, 29, 197-202. doi:10.1021/ar9501582

59. Schrader, T. E.; Schreier, W. J.; Cordes, T.; Koller, F. O.; Babitzki, G.; Denschlag, R.; Renner, C.; Löweneck, M.; Dong, S.-L.; Moroder, L.; Tavan, P.; Zinth, W. Proc. Natl. Acad. Sci. U. S. A. 2007, 104, 15729-15734. doi:10.1073/pnas.0707322104

60. Asanuma, H.; Liang, X.; Nishioka, H.; Matsunaga, D.; Liu, M.; Komiyama, M. Nat. Protoc. 2007, 2, 203-212. doi:10.1038/nprot.2006.465

61. Srinivas, O.; Mitra, N.; Surolia, A.; Jayaraman, N. J. Am. Chem. Soc. 2002, 124, 2124-2125. doi:10.1021/ja0173066

62. Guerrero, L.; Smart, O. S.; Weston, C. J.; Burns, D. C.; Woolley, G. A.; Allemann, R. K. Angew. Chem., Int. Ed. 2005, 44, 7778-7782. doi:10.1002/anie.200502666

63. Caamaño, A. M.; Vázquez, M. E.; Martínez-Costas, J.; Castedo, L.; Mascareñas, J. L. Angew. Chem., Int. Ed. 2000, 39, 3104-3107. doi:10.1002/1521-3773(20000901)39:17<3104::AID-ANIE3104>3.0.C O;2-0

64. Westmark, P. R.; Kelly, J. P.; Smith, B. D. J. Am. Chem. Soc. 1993, 115, 3416-3419. doi:10.1021/ja00062a003

65. Hohsaka, T.; Kawashima, K.; Sisido, M. J. Am. Chem. Soc. 1994, 116, 413-414. doi:10.1021/ja00080a064

66. Nakayama, K.; Endo, M.; Majima, T. Chem. Commun. 2004, 2386-2387. doi:10.1039/b409844g

67. Willner, I.; Rubin, S.; Riklin, A. J. Am. Chem. Soc. 1991, 113, 3321-3325. doi:10.1021/ja00009a016

68. Dong, S.-L.; Löweneck, M.; Schrader, T. E.; Schreier, W. J.; Zinth, W.; Moroder, L.; Renner, C. Chem.-Eur. J. 2006, 12, 1114-1120. doi:10.1002/chem.200500986

69. Woolley, G. A.; Jaikaran, A. S. I.; Berezovski, M.; Calarco, J. P.; Krylov, S. N.; Smart, O. S.; Kumita, J. R. Biochemistry 2006, 45, 6075-6084. doi:10.1021/bi060142r

70. Renner, C.; Kusebauch, U.; Löweneck, M.; Milbradt, A. G.; Moroder, L. J. Pept. Res. 2005, 65, 4-14. doi:10.1111/j.1399-3011.2004.00203.x

71. Pieroni, O.; Fissi, A.; Angelini, N.; Lenci, F. Acc. Chem. Res. 2001, 34, 9-17. doi:10.1021/ar990141+

72. Renner, C.; Moroder, L. ChemBioChem 2006, 7, 868-878. doi:10.1002/cbic.200500531

73. Aaemissegger, A.; Kräutler, V.; van Gunsteren, W. F.; Hilvert, D. J. Am. Chem. Soc. 2005, 127, 2929-2936. doi:10.1021/ja0442567 
74. Beharry, A. A.; Woolley, G. A. Chem. Soc. Rev. 2011, 40, 4422-4437. doi:10.1039/c1cs15023e

75. Sadovski, O.; Beharry, A. A.; Zhang, F.; Woolley, G. A. Angew. Chem., Int. Ed. 2009, 48, 1484-1486. doi:10.1002/anie.200805013

76. Beharry, A. A.; Sadovski, O.; Woolley, G. A. J. Am. Chem. Soc. 2011, 133, 19684-19687. doi:10.1021/ja209239m

77. Cruz, F. G.; Koh, J. T.; Link, K. H. J. Am. Chem. Soc. 2000, 122, 8777-8778. doi:10.1021/ja001804h

78. Stawski, P.; Sumser, M.; Trauner, D. Angew. Chem., Int. Ed. 2012, 51, 5748-5751. doi:10.1002/anie.201109265

79. Tochitsky, I.; Banghart, M. R.; Mourot, A.; Yao, J. Z.; Gaub, B.; Kramer, R. H.; Trauner, D. Nat. Chem. 2012, 4, 105-111. doi:10.1038/nchem.1234

80. Stawski, P.; Janovjak, H.; Trauner, D. Bioorg. Med. Chem. 2010, 18 7759-7772. doi:10.1016/j.bmc.2010.09.012

81. Kramer, R. H.; Fortin, D. L.; Trauner, D. Curr. Opin. Neurobiol. 2009, 19, 544-552. doi:10.1016/j.conb.2009.09.004

82. Fehrentz, T.; Schönberger, M.; Trauner, D. Angew. Chem., Int. Ed. 2011, 50, 12156-12182. doi:10.1002/anie.201103236

83. Lien, L.; Jaikaran, D. C. J.; Zhang, Z.; Woolley, G. A. J. Am. Chem. Soc. 1996, 118, 12222-12223. doi:10.1021/ja962217s

84. Mourot, A.; Kienzler, M. A.; Banghart, M. R.; Fehrentz, T.; Huber, F. M. E.; Stein, M.; Kramer, R. H.; Trauner, D. ACS Chem. Neurosci. 2011, 2, 536-543. doi:10.1021/cn200037p

85. Hilf, R. J. C.; Bertozzi, C.; Zimmermann, I.; Reiter, A.; Trauner, D.; Dutzler, R. Nat. Struct. Mol. Biol. 2010, 17, 1330-1336. doi:10.1038/nsmb.1933

86. Kaufman, H.; Vratsanos, S. M.; Erlanger, B. F. Science 1968, 162, 1487-1489. doi:10.1126/science.162.3861.1487

87. Deal, W. J.; Erlanger, B. F.; Nachmansohn, D. Proc. Natl. Acad. Sci. U. S. A. 1969, 64, 1230-1234. doi:10.1073/pnas.64.4.1230

88. Banghart, M.; Borges, K.; Isacoff, E.; Trauner, D.; Kramer, R. H. Nat. Neurosci. 2004, 7, 1381-1386. doi:10.1038/nn1356

89. Volgraf, M.; Gorostiza, P.; Numano, R.; Kramer, R. H.; Isacoff, E. Y.; Trauner, D. Nat. Chem. Biol. 2006, 2, 47-52. doi:10.1038/nchembio756

90. Gorostiza, P.; Volgraf, M.; Numano, R.; Szobota, S.; Trauner, D.; Isacoff, E. Y. Proc. Natl. Acad. Sci. U. S. A. 2007, 104, 10865-10870 doi:10.1073/pnas.0701274104

91. Volgraf, M.; Gorostiza, P.; Szobota, S.; Helix, M. R.; Isacoff, E. Y.; Trauner, D. J. Am. Chem. Soc. 2007, 129, 260-261. doi:10.1021/ja067269o

92. Bredenbeck, J.; Helbing, J.; Kumita, J. R.; Woolley, G. A.; Hamm, P. Proc. Natl. Acad. Sci. U. S. A. 2005, 102, 2379-2384 doi:10.1073/pnas.0406948102

93. Guerrero, L.; Smart, O. S.; Woolley, G. A.; Allemann, R. K. J. Am. Chem. Soc. 2005, 127, 15624-15629. doi:10.1021/ja0550428

94. Beharry, A. A.; Wong, L.; Tropepe, V.; Woolley, G. A. Angew. Chem., Int. Ed. 2011, 50, 1325-1327. doi:10.1002/anie.201006506

95. Hunter, C. A.; Togrul, M.; Tomas, S. Chem. Commun. 2004, 108-109. doi:10.1039/b311060e

96. Goodman, A.; Breinlinger, E.; Ober, M.; Rotello, V. M. J. Am. Chem. Soc. 2001, 123, 6213-6214. doi:10.1021/ja0032475

97. Pedersen, C. J. J. Am. Chem. Soc. 1967, 89, 2495-2496. doi:10.1021/ja00986a052

98. Pedersen, C. J. J. Am. Chem. Soc. 1967, 89, 7017-7036. doi:10.1021/ja01002a035
99. Vögtle, F.; Sieger, H.; Müller, W. M. Top. Curr. Chem. 1981, 98, 107-161. doi:10.1007/BFb0111247

100.Vögtle, F.; Müller, W. M.; Watson, W. H. Top. Curr. Chem. 1984, 125, 131-164. doi:10.1007/3-540-13569-3_4

101.Shinkai, S.; Manabe, O. Host Guest Complex Chemistry, Macrocycles; Springer-Verlag: Berlin, 1983.

102. Kimura, K.; Mizutani, R.; Suzuki, T.; Yokoyama, M. J. Inclusion Phenom. Mol. Recognit. Chem. 1998, 32, 295-310. doi:10.1023/A:1008075730071

103. Naemura, K.; Ueno, K.; Takeuchi, S.; Tobe, Y.; Kaneda, T.; Sakata, Y. J. Am. Chem. Soc. 1993, 115, 8475-8476. doi:10.1021/ja00071a078

104. Tamaoki, N.; Wada, M. J. Am. Chem. Soc. 2006, 128, 6284-6285. doi:10.1021/ja058398s

105. Fujimaki, M.; Matsuzawa, Y.; Hayashi, Y.; Ichimura, K. Chem. Lett. 1998, 27, 165-166. doi:10.1246/cl.1998.165

106.Kim, J. S.; Shon, O. J.; Lee, J. K.; Lee, S. H.; Kim, J. Y.; Park, K.-M.; Lee, S. S. J. Org. Chem. 2002, 67, 1372-1375. doi:10.1021/jo0108921

107.Gu, R.; Depraetere, S.; Kotek, J.; Budka, J.; Wagner-Wysiecka, E.; Biernat, J. F.; Dehaen, W. Org. Biomol. Chem. 2005, 3, 2921-2923. doi:10.1039/b507508d

108. Shinkai, S.; Minami, T.; Kusano, Y.; Manabe, O. J. Am. Chem. Soc. 1983, 105, 1851-1856. doi:10.1021/ja00345a029

109.Lahav, M.; Ranjit, K. T.; Katz, E.; Willner, I. Chem. Commun. 1997, 259-260. doi:10.1039/a606189c

110.Jeong, K.-S.; Chang, K.-J.; An, Y.-J. Chem. Commun. 2003, 1450-1451. doi:10.1039/b303269h

111. Norikane, Y.; Tamaoki, N. Org. Lett. 2004, 6, 2595-2598. doi:10.1021/ol049082c

112. Tamaoki, N.; Ogata, K.; Koseki, K.; Yamaoka, T. Tetrahedron 1990, 46, 5931-5942. doi:10.1016/S0040-4020(01)87918-7

113. Tamaoki, N.; Yamaoka, T. J. Chem. Soc., Perkin Trans. 2 1991, 873-878. doi:10.1039/p29910000873

114. Tamaoki, N.; Yoshimura, S.; Yamaoka, T. Thin Solid Films 1992, 221, 132-139. doi:10.1016/0040-6090(92)90806-M

115.Asakawa, M.; Ashton, P. R.; Balzani, V.; Brown, C. L.; Credi, A.; Matthews, O. A.; Newton, S. P.; Raymo, F. M.; Shipway, A. N.; Spencer, N.; Quick, A.; Stoddart, J. F.; White, A. J. P.; Williams, D. J. Chem.-Eur. J. 1999, 5, 860-875. doi:10.1002/(SICI)1521-3765(19990301)5:3<860::AID-CHEM860>3.0 $\mathrm{CO} ; 2-\mathrm{K}$

116. Ballardini, R.; Balzani, V.; Credi, A.; Gandolfi, M. T.; Venturi, M. Acc. Chem. Res. 2001, 34, 445-455. doi:10.1021/ar000170g

117. Muraoka, T.; Kinbara, K.; Kobayashi, Y.; Aida, T. J. Am. Chem. Soc. 2003, 125, 5612-5613. doi:10.1021/ja034994f

118. Muraoka, T.; Kinbara, K.; Aida, T. Chem. Commun. 2007, 1441-1443. doi:10.1039/b618248h

119. Muraoka, T.; Kinbara, K.; Aida, T. Nature 2006, 440, 512-515. doi:10.1038/nature04635

120. Muraoka, T.; Kinbara, K.; Wakamiya, A.; Yamaguchi, S.; Aida, T. Chem.-Eur. J. 2007, 13, 1724-1730. doi:10.1002/chem.200601098

121. Mitchell, G. R.; King, N. R. Macromol. Symp. 1999, 137, 155-165. doi:10.1002/masy.19991370116

122. Vives, G.; Tour, J. M. Acc. Chem. Res. 2009, 42, 473-487. doi:10.1021/ar8002317

123.Sasaki, T.; Tour, J. M. Org. Lett. 2008, 10, 897-900. doi:10.1021/ol703027h

124.Shirai, Y.; Sasaki, T.; Guerrero, J. M.; Yu, B.-C.; Hodge, P.; Tour, J. M. ACS Nano 2008, 2, 97-106. doi:10.1021/nn700294m 
125.Angelos, S.; Johansson, E.; Stoddart, J. F.; Zink, J. I. Adv. Funct. Mater. 2007, 17, 2261-2271.

doi:10.1002/adfm.200601217

126.Angelos, S.; Choi, E.; Vögtle, F.; De Cola, L.; Zink, J. I. J. Phys. Chem. C 2007, 111, 6589-6592. doi:10.1021/jp070721।

127.Lu, J.; Choi, E.; Tamanoi, F.; Zink, J. I. Small 2008, 4, 421-426. doi:10.1002/smll.200700903

128.Schäfer, L. V.; Müller, E. M.; Gaub, H. E.; Grubmüller, H. Angew. Chem., Int. Ed. 2007, 46, 2232-2237. doi:10.1002/anie.200604595

129.Pace, G.; Ferri, V.; Grave, C.; Elbing, M.; von Hänisch, C.; Zharnikov, M.; Mayor, M.; Rampi, M. A.; Samorì, P. Proc. Natl. Acad. Sci. U. S. A. 2007, 104, 9937-9942. doi:10.1073/pnas.0703748104

130.Ferri, V.; Elbing, M.; Pace, G.; Dickey, M. D.; Zharnikov, M.; Samorì, P.; Mayor, M.; Rampi, M. A. Angew. Chem., Int. Ed. 2008, 47, 3407-3409. doi:10.1002/anie.200705339

131.Green, J. E.; Choi, J. W.; Boukai, A.; Bunimovich, Y.; Johnston-Halperin, E.; Delonno, E.; Luo, Y.; Sheriff, B. A.; Xu, K.; Shin, Y. S.; Tseng, H.-R.; Stoddart, J. F.; Heath, J. R. Nature 2007, 445, 414-417. doi:10.1038/nature05462

132. Carreño, M. C.; García, I.; Ribagorda, M.; Merino, E.; Pieraccini, S.; Spada, G. P. Org. Lett. 2005, 7, 2869-2872. doi:10.1021/ol050789o

133.Carreño, M. C.; García, I.; Nuñez, I.; Merino, E.; Ribagorda, M.; Pieraccini, S.; Spada, G. P. J. Am. Chem. Soc. 2007, 129, 7089-7100. doi:10.1021/ja070163o

134.Carreño, M. C.; Fernández Mudarra, G.; Merino, E.; Ribagorda, M. J. Org. Chem. 2004, 69, 3413-3416. doi:10.1021/jo0498011

135. Kahn, S. D.; Hehre, W. J. J. Am. Chem. Soc. 1986, 108, 7399-7400. doi:10.1021/ja00283a040

136.Peters, M. V.; Stoll, R. S.; Kühn, A.; Hecht, S. Angew. Chem., Int. Ed. 2008, 47, 5968-5972. doi:10.1002/anie.200802050

137.Stoll, R. S.; Peters, M. V.; Kühn, A.; Heiles, S.; Goddard, R.; Bühl, M.; Thiele, C. M.; Hecht, S. J. Am. Chem. Soc. 2009, 131, 357-367. doi:10.1021/ja807694s

138.Avellini, T.; Li, H.; Coskun, A.; Barin, G.; Trabolsi, A.; Basuray, A. N.; Dey, S. K.; Credi, A.; Silvi, S.; Stoddart, J. F.; Venturi, M. Angew. Chem., Int. Ed. 2012, 51, 1611-1615. doi:10.1002/anie.201107618

139. Haberhauer, G.; Kallweit, C. Angew. Chem., Int. Ed. 2010, 49, 2418-2421. doi:10.1002/anie.200906731

\section{License and Terms}

This is an Open Access article under the terms of the Creative Commons Attribution License

(http://creativecommons.org/licenses/by/2.0), which permits unrestricted use, distribution, and reproduction in any medium, provided the original work is properly cited.

The license is subject to the Beilstein Journal of Organic Chemistry terms and conditions:

(http://www.beilstein-journals.org/bjoc)

The definitive version of this article is the electronic one which can be found at:

doi:10.3762/bjoc. 8.119 